\title{
Chemically Recuperated Gas Turbines for Offshore Platform: Energy and Environmental Performance
}

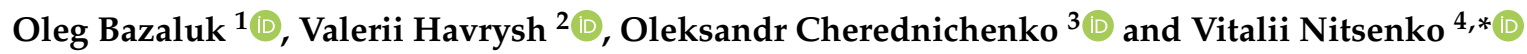 \\ 1 Belt and Road Initiative Institute for Chinese-European Studies, Guangdong University of Petrochemical \\ Technology, Maoming 525000, China; bazaluk@ukr.net \\ 2 Department of Tractors and Agricultural Machinery, Operating and Maintenance, Mykolayiv National \\ Agrarian University, 54020 Mykolaiv, Ukraine; havryshvi@mnau.edu.ua \\ 3 Mechanical Engineering Institute, Admiral Makarov National University of Shipbuilding, 54025 Mykolaiv, \\ Ukraine; oleksandr.cherednichenko@nuos.edu.ua \\ 4 SCIRE Foundation, 00867 Warsaw, Poland \\ * Correspondence: vitaliinitsenko@onu.edu.ua; Tel.: +380-939983073
}

Citation: Bazaluk, O.; Havrysh, V.; Cherednichenko, O.; Nitsenko, V. Chemically Recuperated Gas Turbines for Offshore Platform: Energy and Environmental Performance. Sustainability 2021, 13, 12566. https://doi.org/10.3390/ su132212566

Academic Editor: Farooq Sher

Received: 18 September 2021

Accepted: 10 November 2021

Published: 14 November 2021

Publisher's Note: MDPI stays neutral with regard to jurisdictional claims in published maps and institutional affiliations.

Copyright: (c) 2021 by the authors. Licensee MDPI, Basel, Switzerland. This article is an open access article distributed under the terms and conditions of the Creative Commons Attribution (CC BY) license (https:// creativecommons.org/licenses/by/ $4.0 /)$.

\begin{abstract}
Currently, offshore areas have become the hotspot of global gas and oil production. They have significant reserves and production potential. Offshore platforms are energy-intensive facilities. Most of them are equipped with gas turbine engines. Many technologies are used to improve their thermal efficiency. Thermochemical recuperation is investigated in this paper. Much previous research has been restricted to analyzing of the thermodynamic potential of the chemically recuperated gas turbine cycle. However, little work has discussed the operation issues of this cycle. The analysis of actual fuel gases for the steam reforming process taking into account the actual load of gas turbines, the impact of steam reforming on the Wobbe index, and the impact of a steam-fuel reforming process on the carbon dioxide emissions is the novelty of this study. The obtained simulation results showed that gas turbine engine efficiency improved by 8.1 to $9.35 \%$ at $100 \%$ load, and carbon dioxide emissions decreased by $10 \%$ compared to a conventional cycle. A decrease in load leads to a deterioration in the energy and environmental efficiency of chemically recuperated gas turbines.
\end{abstract}

Keywords: gas turbine; offshore; thermochemical; recuperation; carbon dioxide emission; conversion performance factor; Wobbe index

\section{Introduction}

Mankind is increasing its energy consumption. In 2019, primary energy consumption was 583.9 exajoules. At the same time, oil extraction was 193.03 exajoules (or 33.06\%) and natural gas extraction was 143.62 exajoules (or $24.60 \%$ ). The extraction of liquid and gaseous hydrocarbon constituted $57.66 \%$ of the total primary energy production [1]. Thus, in the 21st century, over half of oil and gas deposits were in offshore areas [2]. Currently, offshore oil and gas production is a valuable source of energy. It has a significant impact on the world economy. About $30 \%$ of oil and $25 \%$ of natural gas are produced from offshore fields. Their proven reserves are $36 \%$ and $46 \%$, respectively [3].

Energy efficiency of offshore vessels and floating oil and gas production facilities is one of the main factors that ensure the efficiency of the logistics chain: productiontransportation-supply of offshore oil and gas [4]. The exploitation of offshore oil and gas fields requires highly specific energy consumption [5]. Offshore platforms are energyintensive facilities. Offshore platforms consume electric power and heat. Gas turbine generators and boilers are used for power supply. As a rule, they use an associated gas as fuel. The energy use depends on the field conditions and its lifetime [6]. Different energysaving strategies have been developed to improve the energy efficiency of platforms. They may be divided into two groups. The first group is to reduce the energy requirements of the oil and gas processing. The second group is to improve the energy performance of an offshore power plant [5]. 
The availability of different gaseous fuels (including natural gas and associated petroleum gas) has resulted in a shift toward gas turbine-based power plants for offshore platforms. Nowadays, gas turbine engines (GTE) are the most widespread energy supply technology for power generation. Simple cycle GTEs have some valuable advantages such as simplicity, flexibility, small space requirements, remote automation, etc. [7]. That is why gas turbine engine units are widely employed in oil and gas offshore platforms [8].

The improvement of energy efficiency can meet the emission targets and decrease fuel consumption [9]. Simple cycle GTEs have a significant potential margin for energy saving and carbon dioxide emission reduction. It can be achieved through the improvement of energy efficiency. Basic GTEs have an efficiency of less than $40 \%$. Exhaust gases have a temperature of 400 to $600{ }^{\circ} \mathrm{C}$. Thus, a significant amount of input energy is wasted with exhaust gases [8].

Energy management is an effective tool to ensure the energy efficiency of any production system $[5,10]$. More than $50 \%$ of the input energy is lost through exhaust gases [11]. Waste heat recovery is employed to utilize it $[11,12]$. The use of waste heat recovery units can achieve significant energy savings and reduce harmful emissions $[13,14]$. However, combined cycle power plants are not widely used because of stringent weight and space constraints $[15,16]$. Waste heat recovery is a promising way for improving the efficiency and environmental friendliness of offshore gas turbines. Thermochemical technologies (which are technologies for waste heat recovery) allow using low-grade alternative fuels. The concept of waste heat thermochemical utilization corresponds to the main trends in the development of marine power plants, given in the analytical review of Global Marine Technology Trends 2030, prepared by Lloyd's Register [17]. According to this forecast, the promising pathways for the next 15 years will include waste heat recovery technologies. Exhaust waste energy could be used to increase thermal efficiency and to reduce harmful emissions, including carbon dioxide. Therefore, waste heat recovery systems have been the subject of much research in recent decades. These systems can significantly increase economic and environmental benefits [18-20]. Combined cycles [21,22], organic Rankine cycles [23-25], and steam injection gas turbines $[26,27]$ can be used to recover the exhaust waste heat.

Chemically recuperated gas turbines combine a fuel-fired gas-turbine cycle with a waste heat chemical recuperation process $[28,29]$. Thermochemical recuperation is a promising technology for gas turbine engines [30-33]. This technology uses endothermic reactions to transform waste energy into the chemical energy of synthetic gaseous fuels. This syngas is a hydrogen-rich combustible gas. It is fed the gas turbine engine. Thus, waste energy can be recovered to enhance the overall efficiency of the thermal engine. This syngas has better combustion characteristics compared to origin fuel. This technology impacts the methane number (MN), the Wobbe index (WI), and heat of combustion [34-36].

Pan et al. [37], Chen et al. [38], and Kyriakides et al. [39] studied thermochemical reformers for methane-steam reforming reactions. Pashchenko $[40,41]$ investigated bioethanol and propane-steam reforming for thermochemical waste heat recuperation. He applied thermodynamics equilibrium analysis for steam-methanol reforming. Pashchenko reported the optimal operation conditions: exhaust gas temperature is from 900 to $1100 \mathrm{~K}$; the steam to methanol ratio is in the range of 1 to 2 ; the optimal operating pressure varies from 0.5 to $1.0 \mathrm{MPa}$ [42].

A chemically recuperated marine gas turbine was studied by Pan et al. [43]. They applied mathematical models for performance analysis. They adopted diesel steam reforming for a waste heat recovery system. Newby et al. [44] studied natural-gas-fueled gas turbine power systems incorporating thermochemical recuperation. They estimated the potential merits of this technological solution. Sadeghi et al. [45] investigated a combined gas turbine and organic Rankine cycle system. They studied the effect of thermochemical recuperation based on methane-steam reforming on its performance. Researchers revealed that the performance is enhanced as the temperature rises. 
Associated petroleum gas is a hydrocarbon feedstock along with oil and natural gas. It can be recycled on-site or used as fuel in offshore power plants. The composition of associated gas varies widely, and it contains heavy hydrocarbons [46-48]. This kind of fuel can cause problems in the working processes of thermal engines. Fuel quality must meet the requirements of the manufacturers of marine thermal engines [49].

However, previous studies did not analyze the thermochemical recuperation of combustible gases which are extracted from offshore oil and gas fields. The Wobbe Index (WI) of syngas has not been investigated enough. The impact of the thermochemical recuperation on carbon dioxide emissions is an important question, too. We assumed the possibility of a complex evaluation methodology for a gas turbine engine integrated with a thermochemical recuperation system as the main hypothesis.

The purpose of this article is to study the energy and environmental efficiency of chemically recuperated gas turbines. Specifically, this study has five objectives. Firstly, to find the range of exhaust gas temperature for steam-fuel conversion. The temperature range is based on actual gas turbines and their operation load. Secondly, to assess the efficiency of steam non-catalytic conversion for gaseous fuels (natural gas and associated gases) is assessed. Thirdly, to analyze the quality of syngas (including the Wobbe Index). Fourthly, to determine the energy efficiency of a chemically recuperated gas turbine. Finally, to determine tank-to-wake carbon dioxide emissions of origin and derived fuels. The chemically recuperated gas turbine efficiency was studied as a function of the load and the kind of fuel gas. The thermochemical steam-fuel reformer is fed by natural gas or an associated gas (actual composition from offshore fields) at actual engine load conditions.

\section{Materials and Methods}

The framework of this paper consists of some parts. The first part describes a chemically recuperated gas turbine cycle. The second part is the analysis of the exhaust gas temperatures and determining their range for further study. This analysis was carried out for offshore gas turbine engines. The third part is the energy estimation of the thermochemical reforming. Natural and associated gases were used for steam reforming. The thermochemical reformer is fed by natural gas or associated gas and steam. In this paper, we study the steam non-catalytic conversion of hydrocarbon fuels. Syngas, which is a product of thermochemical recuperation, is fed into a thermal engine. The properties of each gas component are determined from specialized literature [50]. The specific of this study is an analysis of the Wobbe Index of syngas. The fifth part is devoted to the thermal efficiency of a chemically recuperated gas turbine engine. Finally, tank-to-wake (TTW) carbon dioxide emissions (for origin gases and derived syngas) were calculated.

\subsection{Gaseous Fuels}

The composition of natural and associated gases varies widely. It affects the efficiency of thermochemical treatment. The main components of fuel gases are methane, ethane, propane, butane, and nitrogen. Associated gases contain many chemical compounds, including heavy hydrocarbon. Their compositions are summarized in previous studies (Table 1) [46-48,51,52]. 
Table 1. Composition of gases.

\begin{tabular}{ccccc}
\hline Chemical Compound & $\begin{array}{c}\text { Associated } \\
\text { Gas A1 }\end{array}$ & $\begin{array}{c}\text { Associated } \\
\text { Gas A2 }\end{array}$ & $\begin{array}{c}\text { Associated } \\
\text { Gas A3 }\end{array}$ & $\begin{array}{c}\text { Natural } \\
\text { Gas }\end{array}$ \\
\hline Methane $\left(\mathrm{CH}_{4}\right)(\%)$ & 68.00 & 62.77 & 64.48 & 92.0 \\
Ethane $\left(\mathrm{C}_{2} \mathrm{H}_{6}\right)(\%)$ & 15.00 & 15.07 & 11.98 & 4.3 \\
Propane $\left(\mathrm{C}_{3} \mathrm{H}_{8}\right)(\%)$ & 9.00 & 6.64 & 8.75 & 2.9 \\
Butane $\left(\mathrm{C}_{4} \mathrm{H}_{10}\right)(\%)$ & 5.00 & 2.40 & 3.84 & \\
Pentane and Heaver $(\mathrm{C} 5+)(\%)$ & 1.00 & 1.12 & 2.02 & \\
Hydrogen Sulfide $\left(\mathrm{H}_{2} \mathrm{~S}\right)(\%)$ & & 2.80 & 0.57 & \\
Carbon Dioxide $\left(\mathrm{CO}_{2}\right)(\%)$ & 1.00 & & 3.73 & \multirow{2}{*}{0.8} \\
Nitrogen $\left(\mathrm{N}_{2}\right)(\%)$ & 1.00 & & 4.73 & \\
Water vapor $\left(\mathrm{H}_{2} \mathrm{O}\right)(\%)$ & & & & \\
\hline
\end{tabular}

\subsection{Steam Reforming}

Steam-fuel reforming reactions are endothermic. Exhaust waste heat is a source of energy for these reactions. In our study, we simplified the complex reforming process. The products of this reaction are carbon monoxide, carbon oxide, hydrogen, light hydrocarbons, and water. In our calculations, we use the following assumptions: all gases are treated as ideal gases; there are no losses in heat exchangers; and there is a chemical equilibrium in the reformer (the equilibrium value is a function of temperature, pressure, and steam to gas ratio). Researchers use the theory of chemical equilibrium to shift reaction towards maximum hydrogen yield $[53,54]$. Adiya et al. [55] conducted an equilibrium analysis in regard to hydrogen production from shale gas. An equilibrium analysis based on the minimization of Gibbs energy for steam-methane reforming has been applied by [42,56]. This technique allows scientists to calculate the overall reforming process. They can determine the influence of all input factors on syngas production [57-59]. This method is used to obtain equilibrium product and its composition [60-64]. In [64-68] used an equilibrium model for the analysis of the reforming process. The above simulation was validated by the data from a reforming industrial plant at a petrochemical refinery (Puertollano, Spain).

The Aspen Plus software was used for the simulation.

\subsection{Wobbe Index}

The Wobbe Index (WI) is used to compare different gaseous fuels for gas turbine engines. This index is calculated by Equation (1) [69] as follows:

$$
\mathrm{WI}=\frac{L H V}{\sqrt{\frac{\rho_{g f}}{\rho_{\text {air }}}}},\left[\mathrm{MJ} / \mathrm{m}^{3}\right]
$$

where $L H V$ is the lower heating value of gaseous fuel $\left(\mathrm{MJ} / \mathrm{nm}^{3}\right) ; \rho_{g f}$ is the density of the gaseous fuel at standard conditions (temperature is equal to $0{ }^{\circ} \mathrm{C}$, pressure is equal to $101.325 \mathrm{kPa})$; and $\rho_{\text {air }}$ is the density of air at standard conditions $\left(\mathrm{kg} / \mathrm{m}^{3}\right)$.

\subsection{Efficiency Indicators}

In this study, we use the following efficiency indicators:

- lower heating values of primary gaseous fuels and derived fuels (syngas);

- conversion performance factor;

- the engine efficiency;

- $\quad$ waste heat recovery factor.

Syngas (a product of thermochemical recuperation) has a higher heating value than the origin fuel [70]. Low pressure, high temperature, and high steam to fuel ratio increase the conversion performance factor $(C P F)$. The conversion performance factor is the energy ratio 
between the converted fuel and the fuel input [71]. This increase in the heat of combustion is used as a criterion [72]. This criterion is determined as follows:

$$
C P F=100 \cdot S M F \cdot L H V s \cdot(O F M F \cdot L H V o f)^{-1},[\%],
$$

where $S M F$ is the syngas (produced by thermochemical conversion from one kilogram of origin fuel) mass flow rate $(\mathrm{kg} / \mathrm{s}) ; O F M F$ is the origin gaseous fuel mass flow rate $(\mathrm{kg} / \mathrm{s})$; $L H V s$ is the lower heating value of syngas $(\mathrm{kJ} / \mathrm{kg})$; and LHVof is the lower heating value of origin gaseous fuel $(\mathrm{kJ} / \mathrm{kg})$.

The waste heat recovery factor (WHRF) is calculated by Equation (3) below [73]:

$$
\text { WHRF }=\left(\eta_{T C R}-\eta_{0}\right) \cdot\left(1-\eta_{0}\right)^{-1}
$$

where $\eta_{T C R}$ is the gas turbine engine efficiency with thermochemical recuperation, and $\eta_{0}$ is the gas turbine engine efficiency without thermochemical recuperation.

The application of thermochemical recuperation increases the engine efficiency as follows:

$$
\eta_{T C R}=C P F \cdot(P e p-P p) \cdot(O F M F \cdot L H V o f)^{-1}=0.01 \cdot C P F \cdot \eta_{0} \cdot(P e p-P p) \cdot P e p^{-1}
$$

where Pep is the engine power output $(\mathrm{kW})$, and $P p$ is the power consumed by auxiliary mechanisms of a heat recovery system (pumps, compressors, etc.) $(\mathrm{kW})$.

\subsection{Carbon Dioxide Emission Indicator}

Fuels have different carbon contents and, therefore, they differ in their specific carbon dioxide emissions (SCDE) per unit of energy. If one kilogram of carbon is burned completely, then it produces $11 / 3 \mathrm{~kg}$ of carbon dioxide. This indicator is determined by Equation (5) [74] as follows:

$$
S C D E=11 \cdot C C \cdot(3 \cdot L H V)^{-1},\left[\mathrm{kgCO}_{2} / \mathrm{kJ}\right] .
$$

Tank-to-wake specific carbon dioxide emissions (TTW) are calculated by the following Equation (6):

$$
T T W=13,200 C C \cdot(\eta \cdot L H V)^{-1},[\mathrm{~kg} / \mathrm{kWh}],
$$

where $\eta$ is the engine efficiency, and CC is the carbon content in the fuel $(\mathrm{kg} / \mathrm{kg})$.

In this Equation, we take into account that $1 \mathrm{kWh}$ is equal to $3600 \mathrm{~kJ}$. This indicator is directly proportional to the carbon content in fuel and inversely proportional to the engine efficiency. To improve the TTW and SFCDE indicators, we should raise the engine efficiency and reduce the carbon content in fuel. The thermochemical recuperation increases the engine efficiency. Therefore, it results in a decrease in greenhouse gas emissions.

\section{Results and Discussion}

\subsection{Chemically Recuperated Gas Turbine Cycle}

Chemically recuperated gas turbines use a reforming process to convert origin hydrocarbon fuel into a hydrogen-rich fuel mixture. The advantage of this process is as follows. It absorbs heat from exhaust gases and increases the heating value of a fuel. It reduces nitrogen oxides emissions. There are two primary reforming schemes: steam reforming and flue gas recycling [75]. We suggest a modified steam reforming scheme (Figure 1). A feature of this scheme is the removal of water from the synthesis gas. This solution makes it possible to increase the lower heating value of the combustible gas. In addition, a significant reduction in the volume and mass of synthesis gas greatly simplifies its supply to the combustion chamber. Moreover, a significant amount of water is returned to the cycle, which took part in the steam reforming. In this system, atmospheric air is compressed to be fed into the combustor. Here it is mixed with syngas. The products of combustion power the turbine. Then exhaust gases go through the reformer and the heat recovery steam generator. The live steam and original fuel gas are mixed in the reformer. Steam gaseous fuel reforming is carried out in the reactor. This reaction is endothermic. Its 
product is syngas. This gas is a mixture of hydrogen, carbon dioxide, carbon monoxide, steam, etc. Reforming adds energy recovered from the exhaust gas to energy contained by the fuel. Thus, part of the waste heat is recovered. At the outlet of the reformer, syngas contains up to $40 \%$ of water (steam) [76]. The large volume of steam reduces its lower heating value. Steam-diluted combustion requires the use of special burners [77]. After reforming, syngas goes through coolers, and the steam trap removes water. This water is returned to the cycle to be used for thermochemical recuperation. Dried syngas is fed into the combustor.

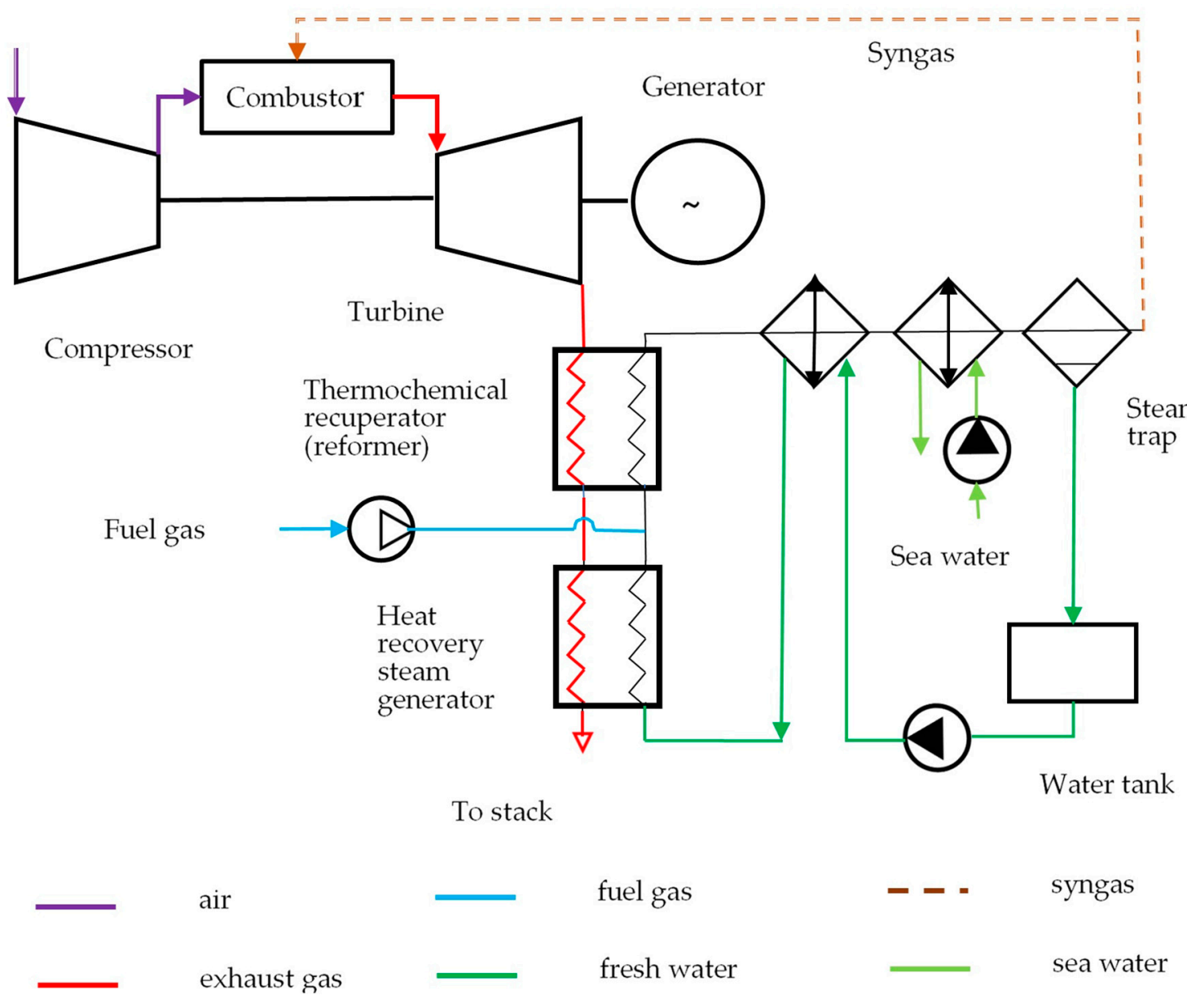

Figure 1. Chemically recuperated gas turbine system.

\subsection{Exhaust Gas Temperature and Pressure}

The main factors influencing the efficiency of waste heat thermochemical treatment can be divided into two groups. The first group of factors depends on the characteristics of heat engines (the exhaust gas temperature, the exhaust mass flow, and the parameters of the fuel gas supply system). The properties of fuels determine the factors of the second group. Thermal engines are supplied by gaseous fuels under high pressure. Mediumspeed diesel engines need pressure in the range of 0.6 to $0.7 \mathrm{MPa}$. The gas supply pressure for low-speed engines is up to $30 \mathrm{MPa}$. The fuel supply pressure of turbine engines ranges from 2 to $3 \mathrm{MPa}$. Regenerative gas turbine engines are fueled by gaseous fuel under pressure in the range of 1.0 to $1.5 \mathrm{MPa}$. In our study, we assumed a pressure of $2 \mathrm{MPa}$.

To determine the prospects of waste heat thermochemical fuel treatment, we should assess the waste energy potential and analyze fuel characteristics. Power modules based on gas turbine engines have the highest exhaust gas temperatures, which vary from 620 to $850 \mathrm{~K}$. Figure 2 reports the manufacturer data [78], showing the variation of the exhaust gas temperatures at full load. These gas turbine engines are characterized by 
outputs ranging between 1 and $58 \mathrm{MW}$. The exhaust gas temperatures do not exceed $573^{\circ} \mathrm{C}$. The temperature affects the amount of energy that can be recovered and the efficiency of thermochemical reforming.

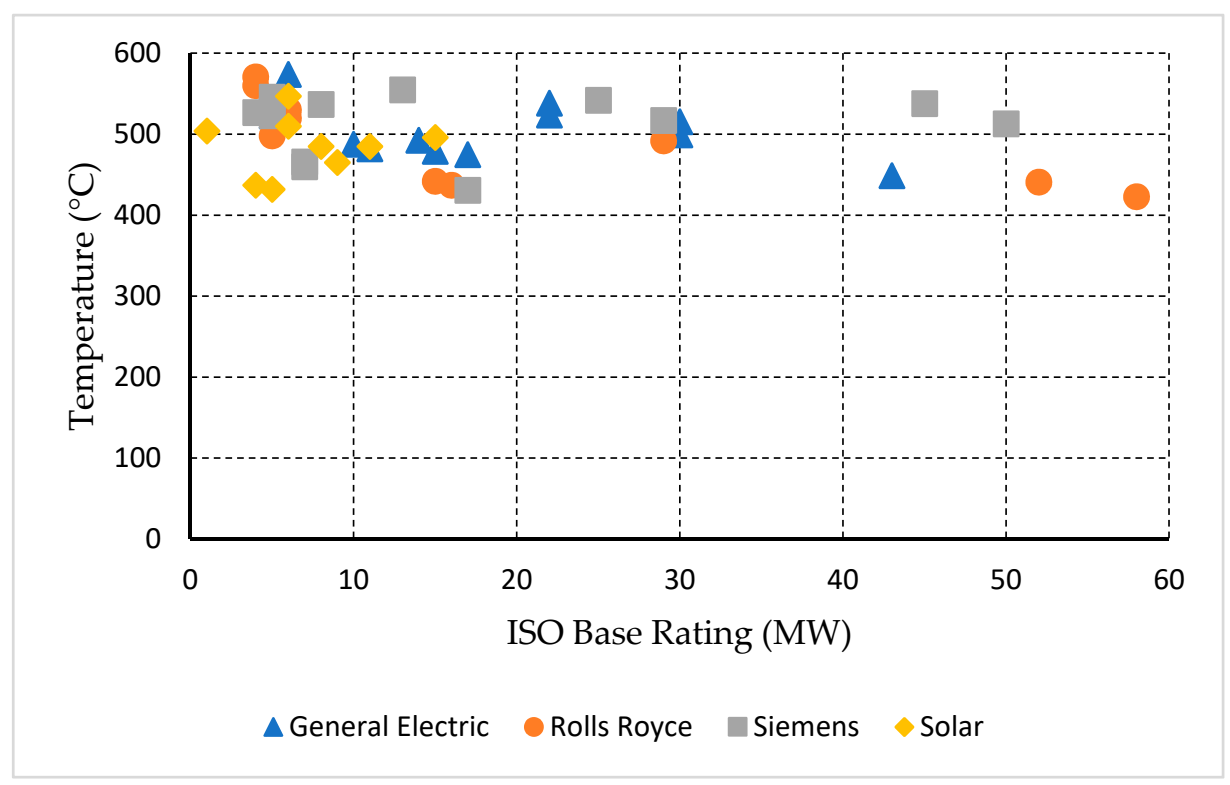

Figure 2. Exhaust gas temperature at full load $\left({ }^{\circ} \mathrm{C}\right)$.

The exhaust gas temperature is a linear function of the gas turbine engine load with many regulation strategies [7]. The parameters of the equations below are determined based on the analysis of gas turbine engines. Manufacturers apply three regulation strategies. The first strategy is a variable amount of fuel injected in the combustion chamber at constant shaft speed. This strategy is used by single-shaft gas turbines. A decrease in load leads to a decline in temperature. For a load range of gas turbine engines from 40 to $100 \%$, the exhaust temperatures vary with the gas turbine load [7] as follows:

$$
t_{e g}=t_{40}-2.75 \cdot(100-L F),\left[{ }^{\circ} \mathrm{C}\right],
$$

where $t_{40}$ is the exhaust gas temperature at full load $\left[{ }^{\circ} \mathrm{C}\right]$, and $L F$ is the load factor of the gas turbine engine [\%].

The second strategy is variable compressor geometry. This kind of regulation allows gas turbine engines to work without a decrease in the operating temperature at part load. The third strategy is the variable shaft speed of a gas generator. This kind of regulation strategy is used by multi-shaft gas turbine engines. In this case, a decrease in load results in declines in both the exhaust temperature and the exhaust mass flow. For the same load range, the exhaust temperature function on load factor is as follows [7]:

$$
t_{\text {eg }}=t_{40}-1.67 \cdot(100-L F),\left[{ }^{\circ} \mathrm{C}\right] .
$$

For our study, a range of exhaust temperatures is determined as follows. A maximum temperature is found in Figure 1. Thus, the maximum temperature has been assumed of $573^{\circ} \mathrm{C}$. Offshore gas turbine engines do not run at the full load. Mazzetti et al. [79] reported that for a long time of the field lifetime, the load ranges from 60 to $70 \%$. A load of gas turbine engines ranges from 25 to $100 \%$ [80]. The average gas turbine load was determined at around $60 \%$. The majority of gas turbine engines have $60-70 \%$ load (Figure 3). That is why a minimum temperature is calculated as an exhaust temperature at $60 \%$ load for a gas turbine engine having a minimum exhaust temperature at ISO base rating. In our case, the minimum exhaust temperature is equal to $313^{\circ} \mathrm{C}$. Diesel engines have different exhaust temperatures. For example, according to the Wärtsilä 50DF Product Guide, a 
temperature after a turbocharger at $100 \%$ load is $380{ }^{\circ} \mathrm{C}$, and the same temperature at $50 \%$ load increases to $430{ }^{\circ} \mathrm{C}$ [81]. At the same loads, the temperatures for $46 \mathrm{DF}$ are $365^{\circ} \mathrm{C}$ and $449{ }^{\circ} \mathrm{C}$, respectively [82].

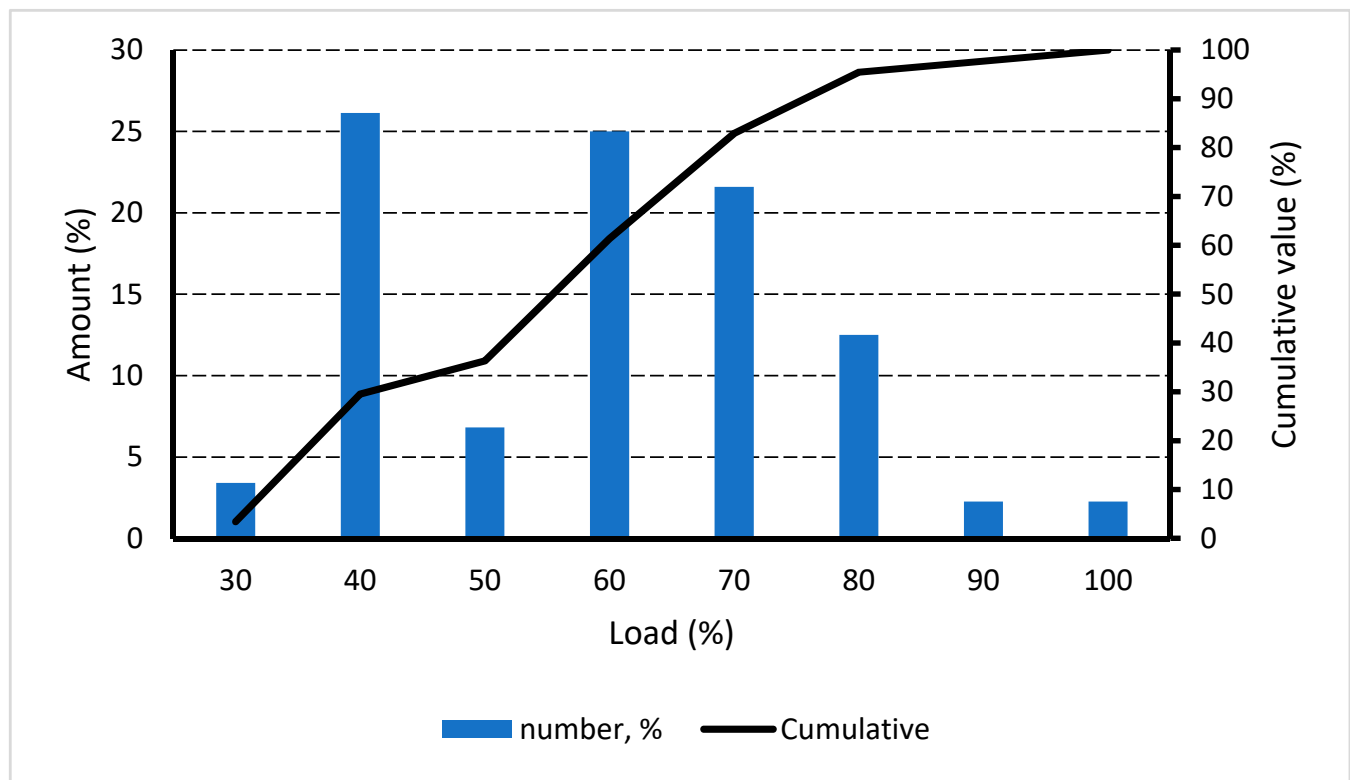

Figure 3. Distribution of offshore gas turbine load.

\subsection{Thermochemical Conversion}

We calculated the conversion performance factor as a function of a temperature and the steam to fuel ratio at fixed pressures. The conversion performance factor is calculated by using Equation (2). According to our mathematical modeling, the increase in pressure requires a higher temperature for high-efficiency fuel gas conversion. This result coincides with the results of other researchers [83]. It was found that an increase in pressure requires an increase in the steam to gas ratio to ensure effective conversion. We studied the impact of temperature (at constant pressure) and the steam to fuel ratio on the conversion performance factor for natural and associated gases (Figure 4). For the temperature of $923 \mathrm{~K}$, the optimal steam to fuel ratio ranges from 4 to 6 . A decrease in temperature requires an increase in this ratio. The possible values of a steam to fuel ratio are investigated. The simulation revealed the impact of gas turbine power on this ratio. According to our calculations, this ratio varies from 6 to 7.5. This ratio is a decreasing function (Figure 5) [84]. Therefore, in our further calculations, we use the live steam to fuel ratio of 6 . 


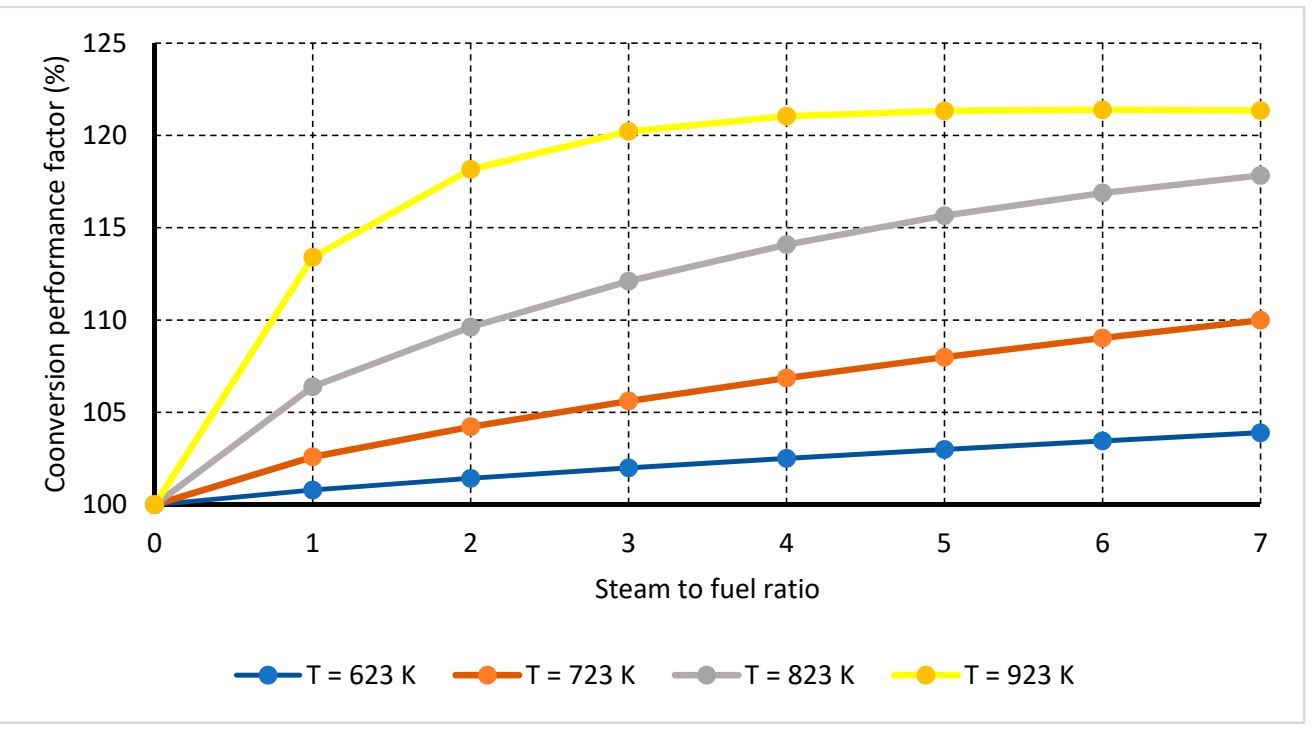

Figure 4. Conversion performance factor versus a steam to fuel ratio and temperature.

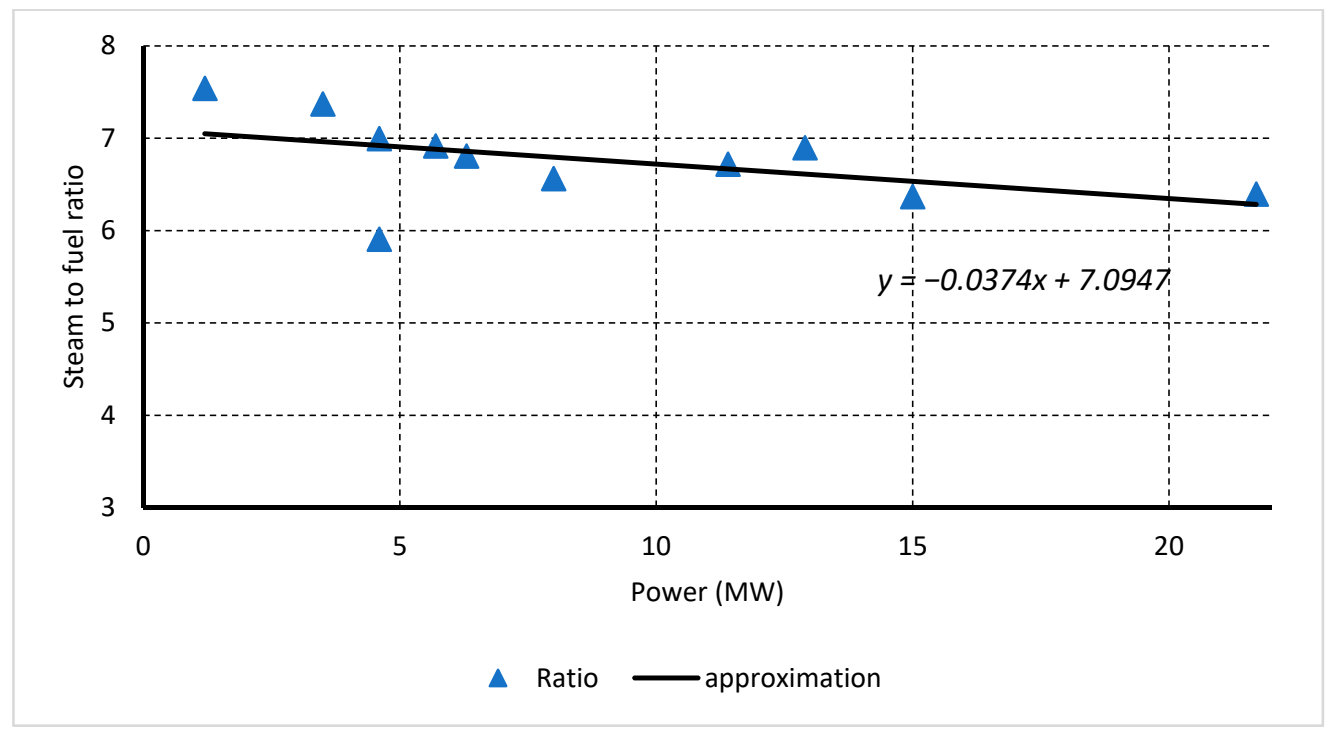

Figure 5. Maximum possible a live steam to fuel ratio versus turbine power.

\subsection{The Quality of Fuel Gas}

The fuel composition impacts the economic and environmental efficiency of gas turbines. Gaseous fuels can be categorized by the Wobbe Index. We use Equation (1) to calculate it. The Wobbe index is an indication of energy flow. If this index is very different from the design value, then a fuel supply system needs changes. If gaseous fuels have similar Wobbe indices (deviation within $\pm 10 \%$ ), they can be substituted without additional adjustment to the fuel supply system. The basic properties of origin gases are presented in Table 2. Due to selected gases having methane numbers less than 80 , they cannot be used as fuels for internal combustion engines. According to gaseous fuel classification, fuels A1 and A2 have high energy density and fuels A4 and NG have standard energy density [69]. 
Table 2. Basic properties of selected gases.

\begin{tabular}{cccccc}
\hline Indicator & Unit & A1 & A2 & A3 & NG \\
\hline Density & $\mathrm{kg} / \mathrm{m}^{3}$ & 1.067 & 1.047 & 1.063 & 0.784 \\
Lower heating value & $\mathrm{MJ} / \mathrm{m}^{3}$ & 51.020 & 46.350 & 42.967 & 38.369 \\
& $\mathrm{MJ} / \mathrm{kg}$ & 47.817 & 44.290 & 40.424 & 48.926 \\
Carbon content & $\mathrm{kg} / \mathrm{kg}$ & 0.776 & 0.750 & 0.686 & 0.588 \\
Wobbe Index & $\mathrm{MJ} / \mathrm{m}^{3}$ & 56.160 & 51.516 & 47.387 & 49.264 \\
Methane Number & & 51.2 & 58.5 & 67.9 & 79.0 \\
\hline
\end{tabular}

Steam reforming results in a decrease in the Wobbe Index (Figure 6). This is a result of a change in chemical composition. Syngas contains more hydrogen. Synthetic fuel gas has a lower density and calorific value (volumetric) compared to the original fuel. Table 3 shows the properties of syngas obtained from natural gas. An increase in the reaction temperature leads to a change in its composition. An increase in hydrogen content is observed. However, syngas contains from $13.97 \%$ to $18.89 \%$ inert compounds (water and carbon dioxide). All these factors lead to a decrease in density and lower heating value. The calculation for associated gases gives similar results.

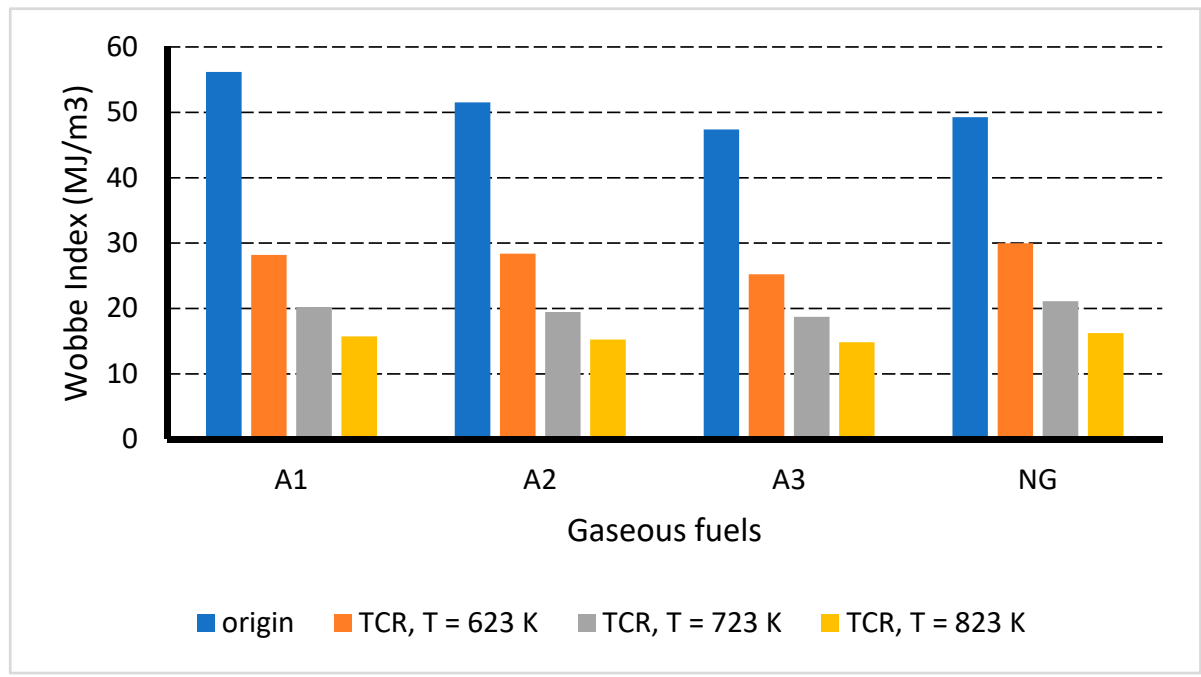

Figure 6. Wobbe Index versus temperature of steam reforming.

Table 3. Properties of syngas.

\begin{tabular}{cccccccc}
\hline \multirow{2}{*}{ Tempera-Ture (K) } & \multirow{2}{*}{ Density $\left(\mathbf{k g} / \mathbf{m}^{\mathbf{3}}\right)$} & \multirow{2}{*}{$\mathbf{L H V}\left(\mathbf{M J} / \mathbf{m}^{\mathbf{3}}\right)$} & $\mathbf{6}$ Content $\mathbf{( \% )}$ \\
& & & $\mathbf{H}_{\mathbf{2}} \mathbf{O}$ & $\mathbf{C O}_{\mathbf{2}}$ & $\mathbf{H}_{\mathbf{2}}$ & $\mathbf{C H}_{\mathbf{4}}$ & $\mathbf{C O}$ \\
\hline 623 & 0.612 & 20.613 & 2.69 & 11.28 & 40.09 & 31.37 & 0.11 \\
723 & 0.535 & 13.582 & 2.69 & 15.62 & 61.53 & 19.12 & 0.79 \\
823 & 0.485 & 9.957 & 2.69 & 16.20 & 72.84 & 4.67 & 3.43 \\
\hline
\end{tabular}

\subsection{Energy Efficiency}

We estimated the conversion performance factor (Equation (2) is used) for operating conditions of offshore gas turbines: the range of exhaust temperatures-from 600 to $900 \mathrm{~K}$; the steam to fuel ratio-6. Natural gas and associated gases are considered fuel gases. The conversion performance factor gradually increases versus temperature (Figure 7). At full load (when the exhaust temperature is maximum), the conversion efficiency is at the maximum. It ranges from $116 \%$ to $118 \%$. At $60 \%$ load, the conversion performance factor for single-shaft gas turbines tends to be $100 \%$. It means that thermochemical recuperation is ineffective. At the same engine load, multi-shaft gas turbines have the conversion performance factor of $104 \%$. At full load, a potential decrease in fuel consumption is up to 
$15 \%$. Its specific value depends on the property of origin gas and the technical parameters of a gas turbine. The typical efficiency versus load for the single-shaft and two-shaft gas turbine engine configurations are presented in Figure 8. Haglin [85] reported the two-shaft configuration has better part-load efficiency.

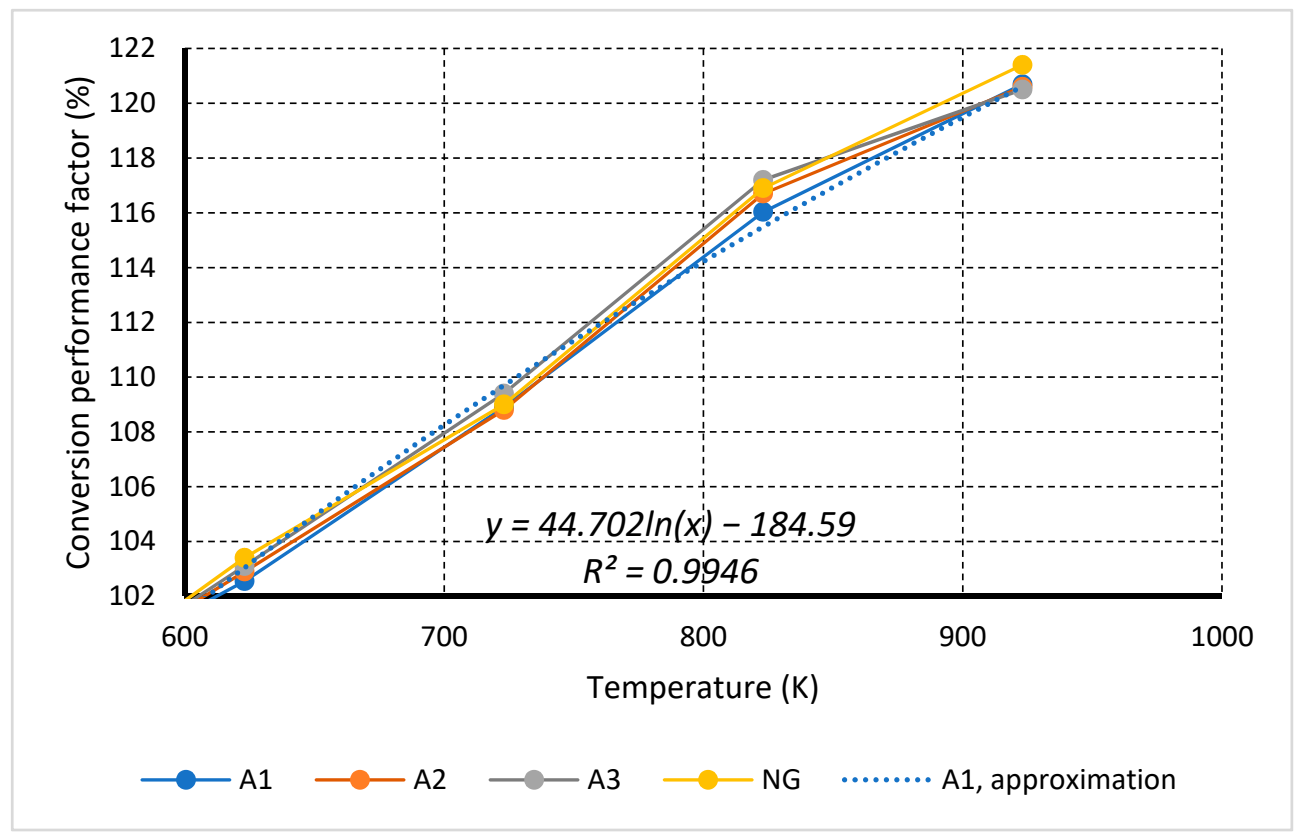

Figure 7. Conversion performance factor versus temperature.

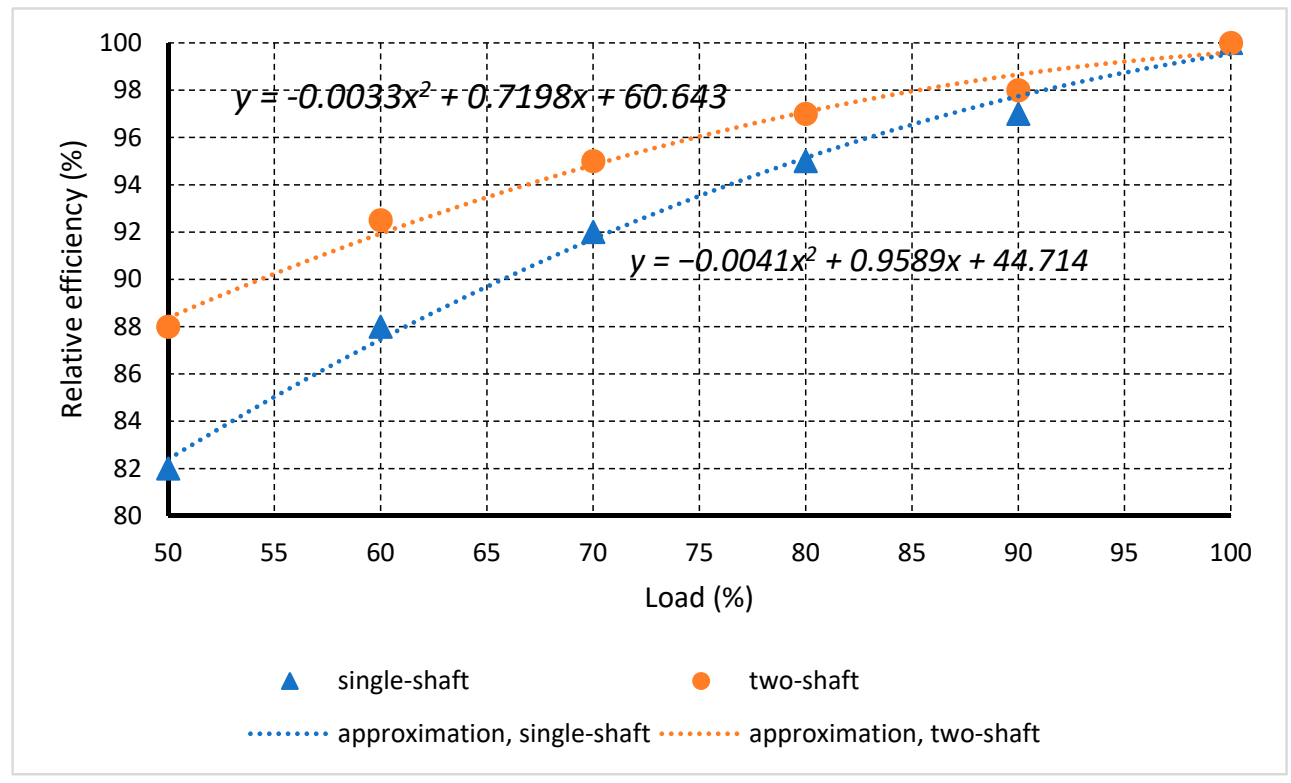

Figure 8. Relative efficiency versus load for single-shaft and two-shaft gas turbines.

We studied a two-shaft gas turbine. The thermal efficiency at $100 \%$ load of the base SGT-600 gas turbine engine [86] and its chemically recuperated version are presented in Figure 9. The engine efficiency is calculated by Equation (4). The technical specifications of SGT-600 are as follows: power generation-24.77 MW; electrical efficiency-34.2\%; and exhaust temperature- $543^{\circ} \mathrm{C}$ [86]. Our calculations show that the use of thermochemical recuperation makes it possible to increase the efficiency by (the absolute value) $2.8-3.2 \%$ or 8.18 to $9.35 \%$ (the relative value). The impact of thermochemical recuperation on thermal 
efficiency is depicted in Figure 10. There is a linear relationship between relative efficiency and load. Increasing the engine load leads to an increase in the waste heat recovery factor (Figure 11). This relationship is linear, too. To find this indicator, we used Equation (3).

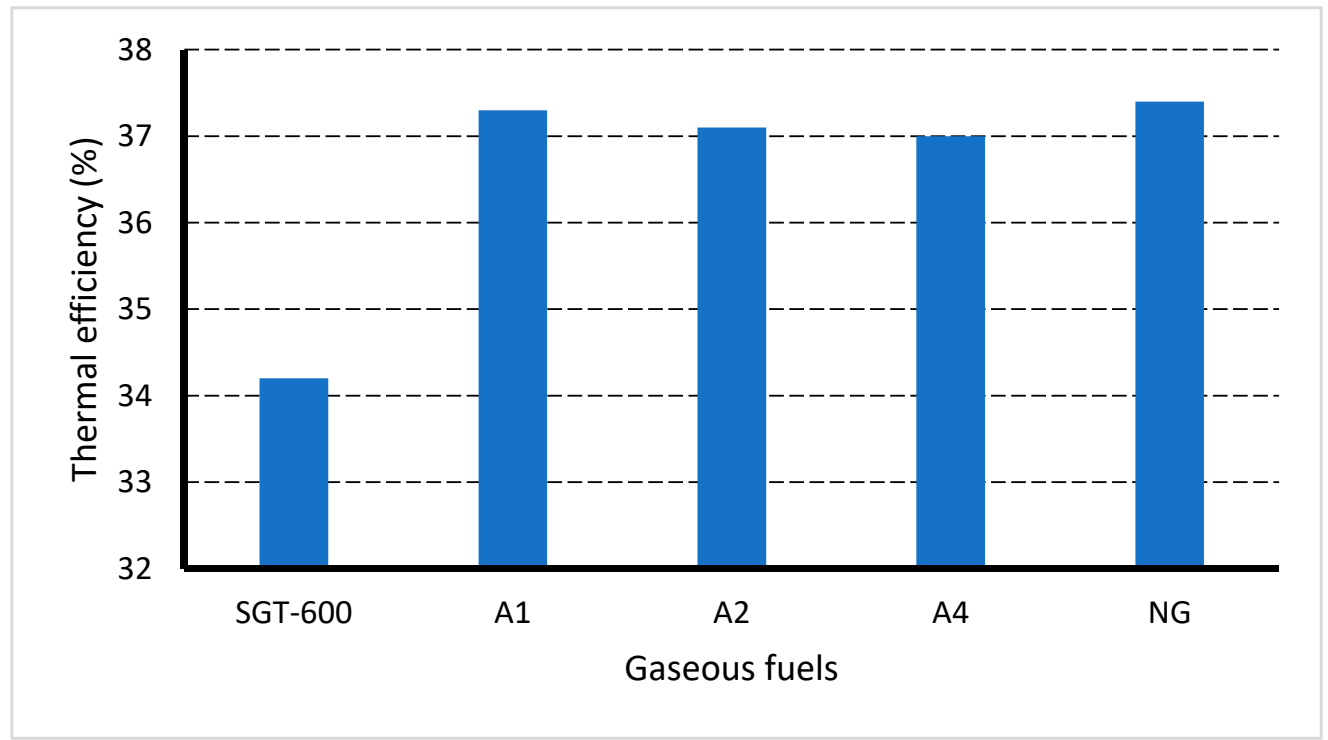

Figure 9. Thermal efficiency for selected origin gases.

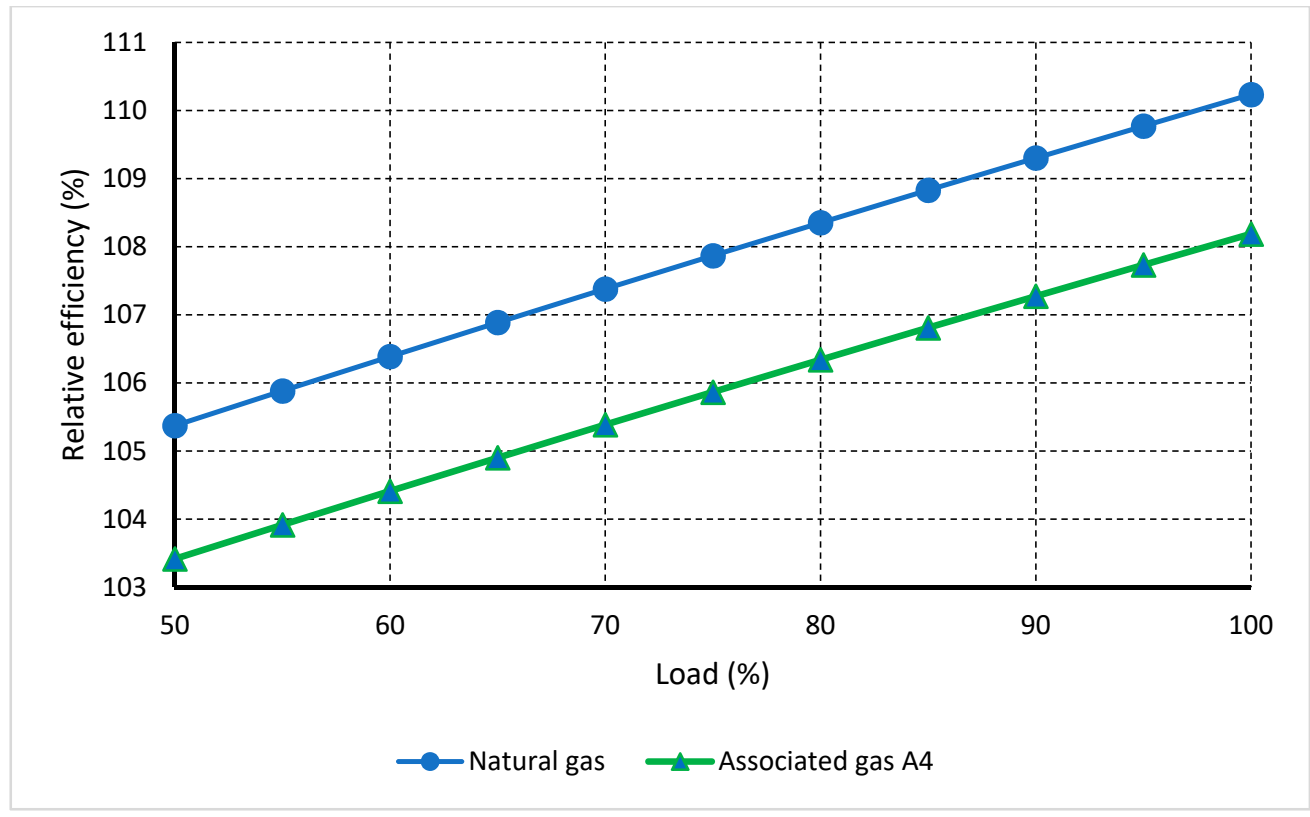

Figure 10. Relative efficiency of the SGT-600 chemically recuperated gas turbine engine. 


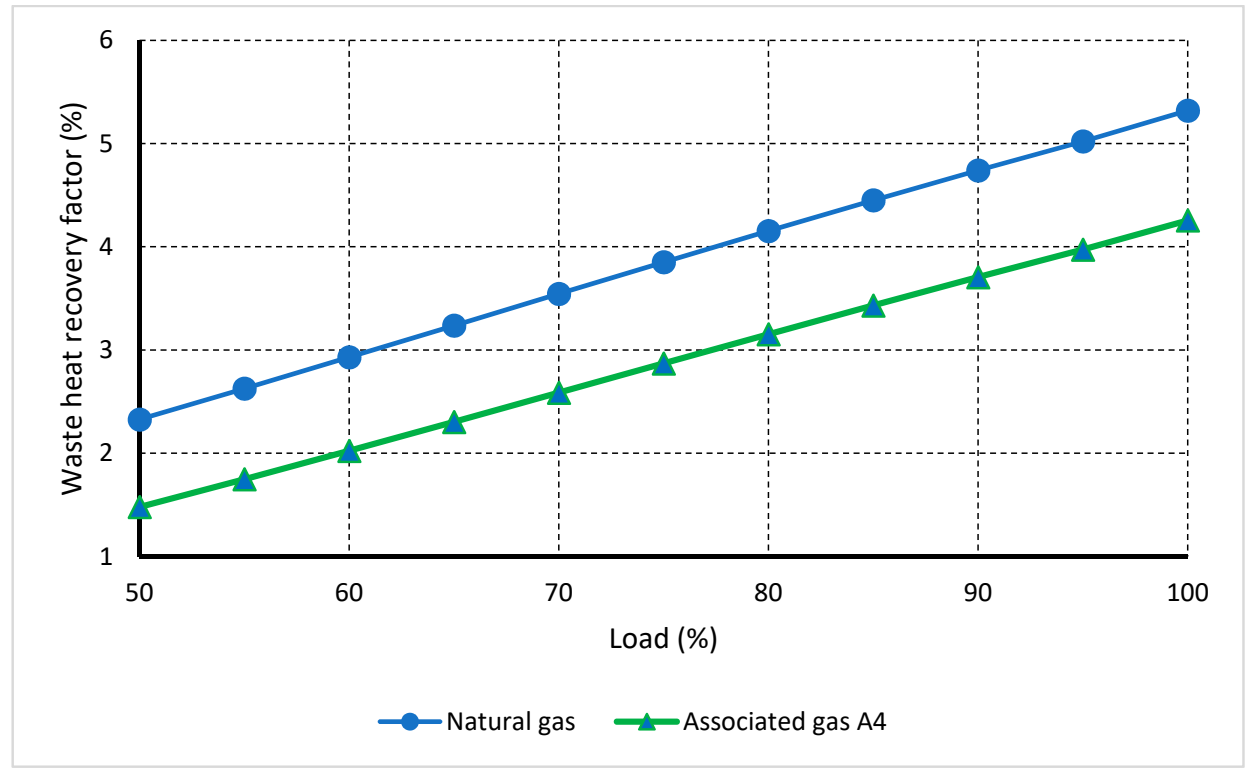

Figure 11. Waste heat recovery factor versus gas turbine engine load.

\subsection{Carbon Dioxide Emission}

Specific carbon dioxide emissions per unit of energy are calculated for origin gaseous fuels and syngas by Equation (5) (Figure 12). The steam-fuel reforming process reduces the specific carbon dioxide emissions per unit of energy by $17 \%$ at a temperature of $823 \mathrm{~K}$. This is a positive fact for environmental indicators of chemically recuperated gas turbines. The tank-to-wake carbon dioxide emissions are calculated by Equation (6). The results are depicted in Figure 13, and their relative values are shown in Figure 14. TTW emissions depend on a gas turbine load. The maximum carbon dioxide emission savings occur at full load. The use of heavy hydrocarbon fuel gas increases carbon dioxide emissions.

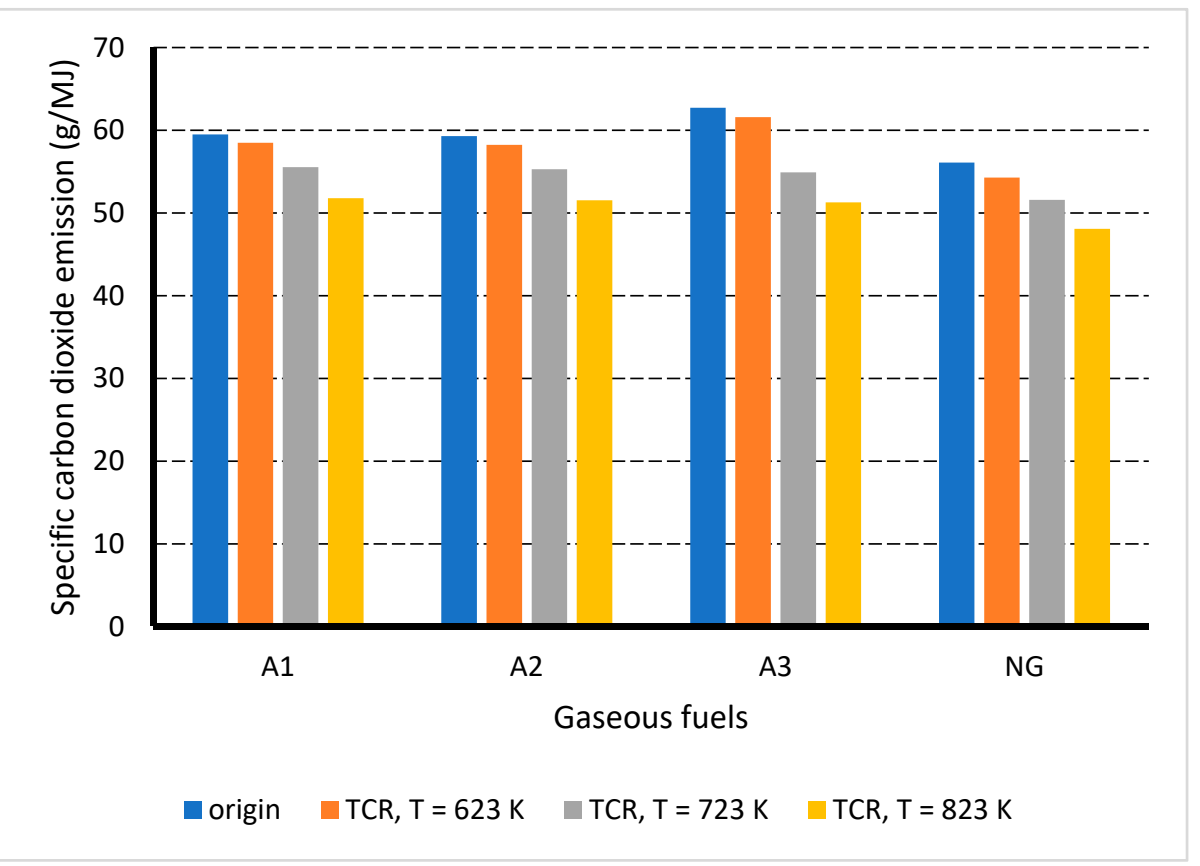

Figure 12. Specific carbon dioxide emission (SCDE) per unit of fuel energy for origin gaseous fuels and syngas. 


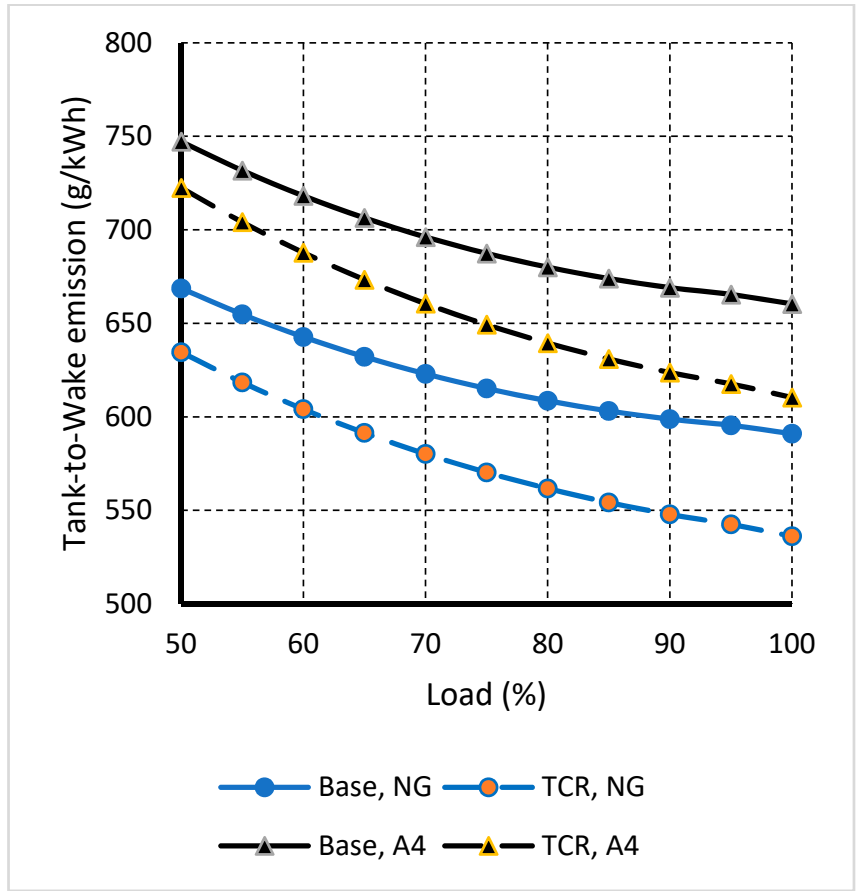

Figure 13. Tank-to-wake (TTW) carbon dioxide emission versus load for different gases.

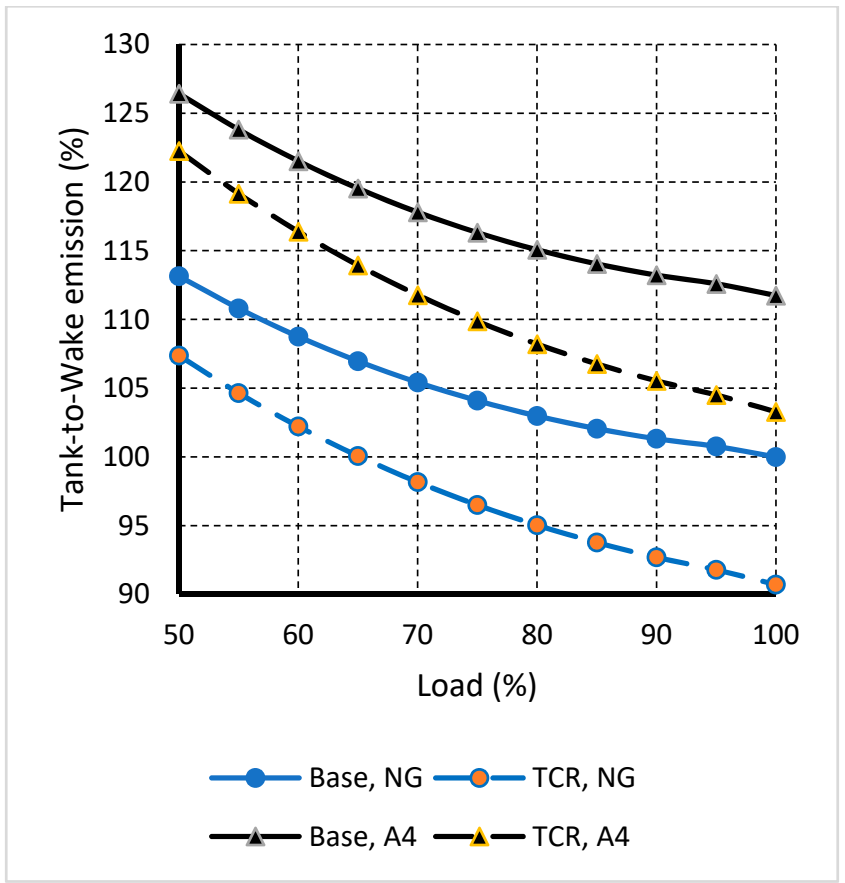

Figure 14. Relative tank-to-wake (TTW) carbon dioxide emission versus load for different gases.

In this paper, we demonstrated a method for increasing the efficiency of gas turbine engines for offshore energy supply systems using a thermochemical recuperation strategy. The development of this strategy is at an early stage, and there are unsolved challenges and barriers to its use for offshore energy supply systems. The purpose of waste heat recovery of gas turbine engines installed on an offshore platform is to reduce specific fuel consumption. The generation of additional power and heat is not an actual task. For this reason, thermochemical recuperation is a suitable solution. Integrating a waste heat thermochemical recuperation results in lower fuel consumption and carbon dioxide 
emissions. However, despite the higher efficiency, the integration of this system requires greater space and weight.

This study has three main results.

Firstly, the conditions for thermochemical recuperation have been determined. The temperatures range from $313{ }^{\circ} \mathrm{C}(586 \mathrm{~K})$ to $573{ }^{\circ} \mathrm{C}(846 \mathrm{~K})$. The upper temperature is taken from reports from manufacturers. Regulation strategies are taken into account to find the lower temperature. Multi-shaft gas turbine engines have a higher exhaust temperature compared to single-shaft ones. Therefore, they have better conditions for thermochemical recuperation. Chemically recuperated gas turbine engines need steam for the reforming process. The conversion performance factor is a function of a temperature and the steam to fuel ratio (Figure 4). The steam to fuel ratio is a decreasing function of output (Figure 5). If the power is less than $5 \mathrm{MW}$, this ratio is higher than 7. Otherwise, this ratio is less than 7. This fact is explained by an increase in the engine thermal efficiency with the rise in power. For this reason, a steam to fuel ratio of 6 was assumed for our calculations.

One important result is the field of application. Chemically recuperated gas turbine engines are better to be used if their load is more than $70 \%$. In this case, an increase in the relative thermal efficiency is more than $3 \%$. Around $30 \%$ of offshore platforms meet this requirement.

The second contribution is the impact of steam reforming on the Wobbe Index. Gas turbines can use a wide range of fuel compositions without changes in fuel supply systems. For example, the Wobbe Index variation for the $9 \mathrm{~F} .05$ gas turbine is $\pm 10 \%$. For the $9 \mathrm{E} .03$ gas turbine and the 9E.04 gas turbine, this variation is broader, and it is equal to $\pm 30 \%$ [87]. According to our calculations, the Wobbe Index of syngas is within the range from 15 to $30 \mathrm{MJ} / \mathrm{m}^{3}$ (Figure 6). Therefore, the application of syngas needs hardware changes.

Syngas contains hydrogen of up to $72 \%$. Gas turbine engines that can use hydrogen blends are being developed by many manufacturers. For example, Siemens has made gas turbine engines that can use fuel blends containing hydrogen of up to $40 \%$ [88]. The General Electric Company has developed a gas turbine engine that can use a 90\% hydrogen blend [89]. For this reason, syngas can be used by turbine engines.

Fuel gas for use in gas turbine engines needs to meet critical features such as the Wobbe Index and calorific value. Siemens has experience in the application of syngas, which have low calorific value. The gas turbine engines of this company were fed by fuel gases with a lower heating value of 4.3 to $9.1 \mathrm{MJ} / \mathrm{m}^{3}$ [90]. An increase in the supply temperature results in a decrease in the Wobbe Index. Acceptable temperatures are in the range of 2.5 to $120^{\circ} \mathrm{C}$. New burner designs allow gas turbine engines to use fuels with a Wobbe Index of 15 to $50 \mathrm{MJ} / \mathrm{m}^{3}$. Commercial gas turbine engines have been developed for the Wobbe Index of circa $21 \mathrm{MJ} / \mathrm{m}^{3}$ [91,92].

In the range of operating exhaust temperatures, the conversion performance factor varies from 10 to $119 \%$ (Figure 7). Its value at part load depends on the type of gas turbine regulation strategy. At part load, multi-shaft gas turbines have higher efficiency compared to single-shaft ones (Figures 8 and 9).

We have analyzed the efficiency of thermochemical recuperation for SGT-600 (a twoshaft gas turbine engine). In our calculations, we have taken into account energy consumed by auxiliary mechanisms such as pumps and a fuel gas compressor. This assumption reduces a potential increase in thermal efficiency. It was found that the chemically recuperated gas turbine cycle increases relative thermal efficiency by around 5 to $10 \%$ for natural gas and 3.2 to $8 \%$ for associated gas, and the waste heat recovery factor ranges from $2.2 \%$ at $50 \%$ load to $5.5 \%$ at full load (for natural gas). The burning of associated gas reduces the waste heat recovery factor to $1.4 \%$ and $4.2 \%$ at the same engine loads (Figure 14).

Finally, the impact of thermal recuperation on carbon dioxide emissions has been determined. Steam reforming reduces carbon dioxide emissions. This rate depends on the type of fuel and a temperature of a steam reforming process. Most reduction in emissions is observed for origin fuels with a high content of heavy hydrocarbons. Syngas has a lower specific carbon dioxide emission, down to $83 \%$ compared to original fuels. 
The tank-to-wake emissions depend on the type of fuel and the engine's thermal efficiency. Chemically recuperated gas turbine engines have low TTW emissions compared to the base version of gas turbine engines. This decrease depends on the load. Lowering the load decreases the exhaust temperature. As a result, the conversion performance factor decreases. The consequence of this is a decrease in the difference between TTW of the based variant and chemically recuperated engines.

The use of thermochemical recuperation drastically decreases the Wobbe Index. Syngas has lower density and calorific value compared to origin fuels. This change impacts the gaseous fuel's interchangeability, and the fuel supply system needs to be adjusted. It requires changes in injection parameters such as area or pressure. This problem is a subject of further research. The economics of chemically recuperated gas turbines are of practical interest. Our previous methods are planned to be applied to investigate economic issues $[93,94]$.

\section{Conclusions}

Thermochemical recuperation can improve the economic and ecological indicators of thermal engines. Chemically recuperated gas turbines for powering offshore platforms were explored in this study and got the following results. Offshore platforms are primarily powered by gas turbines of 1 to $58 \mathrm{MW}$. At full load, their exhaust temperatures range from $420{ }^{\circ} \mathrm{C}$ to $580{ }^{\circ} \mathrm{C}$. This temperature depends on the engine load and its regulation strategy. The average gas turbine load is in the range of $60 \%$ to $70 \%$. At these loads, an exhaust gas temperature is between $313^{\circ} \mathrm{C}$ and $506^{\circ} \mathrm{C}$. The conversion performance factor is a function of temperature and the live steam to fuel ratio. The live steam to fuel ratio of 6 was determined. For natural and associated gases, the conversion performance factor is in the range of $103 \%$ to $118 \%$ for operational conditions. Steam reforming changes a gaseous fuel composition and, therefore, its properties. The density and lower heating value of syngas are lower than those of the original fuel. As a result, there has been a decrease in the Wobbe Index. At full load, a chemically recuperated gas turbine engine has 16-18\% higher efficiency (the relative value) compared to a conventional gas turbine engine. At $60 \%$ load, a single-shaft gas turbine is not affected by thermochemical recuperation. The use of thermochemical recuperation in multi-shaft gas turbine engines has a noticeable increase in its efficiency. Thermochemical recuperation reduces the specific carbon dioxide emissions of fuel by $17 \%$. The maximum tank-to-wake emissions saving is found at full load. It is a result of the higher engine efficiency. The type of fuel impacts TTW, too. The heavier the fuel, the greater the reduction in emissions.

Author Contributions: Conceptualization, V.H.; methodology, V.H. and V.N.; software, O.B.; validation, V.H. and O.C.; formal analysis, V.H. and V.N.; investigation, O.B.; resources, O.B.; data curation, O.C.; writing-original draft preparation, V.H. and V.N.; writing-review and editing, O.B. and V.N.; visualization, O.C.; supervision, V.H. and O.C.; project administration, O.B.; funding acquisition, O.B. All authors have read and agreed to the published version of the manuscript.

Funding: This study was carried out as part of the project "Belt and Road Initiative Institute for Chinese-European studies" and was funded by the Guangdong University of Petrochemical Technology, Maoming, China.

Institutional Review Board Statement: Not applicable.

Informed Consent Statement: Not applicable.

Data Availability Statement: Data sharing not applicable.

Acknowledgments: The authors would like to thank all the quality professionals who helped the research.

Conflicts of Interest: The authors declare no conflict of interest. 


\section{References}

1. Statistical Review of World Energy, 69th Edition. 2020. Available online: https://www.fuelsandlubes.com/bp-releases-2020 -statistical-review-world-energy/ (accessed on 19 June 2021).

2. Zhang, G.; Qu, H.; Chen, G.; Zhao, C.; Zhang, F.; Yang, H.; Zhao, Z.; Ma, M. Giant Discoveries of Oil and Gas Fields in Global Deepwaters in the Past 40 Years and the Prospect of Exploration. J. Nat. Gas Geosci. 2019, 4, 1-28. [CrossRef]

3. Offshore Energy Outlook. International Energy Agency. 2018. Available online: https://iea.blob.core.windows.net/assets/f469 4056-8223-4b14-b688-164d6407bf03/WEO_2018_Special_Report_Offshore_Energy_Outlook.pdf (accessed on 5 August 2021).

4. WOR 3: Marine Resources-Opportunities and Risks. 2014. Available online: https://worldoceanreview.com/en/wor-3 (accessed on 19 June 2021).

5. Nguyen, T.-V.; Voldsund, M.; Breuhaus, P.; Elmegaard, B. Energy Efficiency Measures for Offshore Oil and Gas Platforms. Energy 2016, 117, 325-340. [CrossRef]

6. Bothamley, M. Offshore Processing Options for Oil Platforms. In Proceedings of the SPE Annual Technical Conference 566 and Exhibition, Houston, TX, USA, 26-29 September 2004; Society of Petroleum Engineers Inc.: Richardson, TX, USA, 2004; pp. 1-17. [CrossRef]

7. Ancona, M.A.; Bianchi, M.; Branchini, L.; De Pascale, A.; Melino, F.; Peretto, A.; Torricelli, N. Systematic Comparison of ORC and s- $\mathrm{CO}_{2}$ Combined Heat and Power Plants for Energy Harvesting in Industrial Gas Turbines. Energies 2021, 14, 3402. [CrossRef]

8. Hedman, B.A. Waste Energy Recovery Opportunities for Interstate Natural Gas Pipelines; Interstate Natural Gas Association of America (INGAA): Washington, DC, USA, 2008.

9. Branchini, L.; Bignozzi, M.C.; Ferrari, B.; Mazzanti, B.; Ottaviano, S.; Salvio, M.; Toro, C.; Martini, F.; Canetti, A. Cogeneration Supporting the Energy Transition in the Italian Ceramic Tile Industry. Sustainability 2021, 13, 4006. [CrossRef]

10. Da Silva, J.A.M.; de Oliveira Junior, S. Unit Exergy Cost and $\mathrm{CO}_{2}$ Emissions of Offshore Petroleum Production. Energy 2018, 147, 757-766. [CrossRef]

11. Singh, D.V.; Pedersen, E. A Review of Waste Heat Recovery Technologies for Maritime Applications. Energy Convers. Manag. 2016, 111, 315-328. [CrossRef]

12. Sun, E.H.; Xu, J.L.; Li, M.J.; Liu, G.L.; Zhu, B.G. Connected-Top-Bottom-Cycle to Cascade Utilize Flue Gas Heat for Supercritical Carbon Dioxide Coal Fired Power Plant. Energy Convers. Manag. 2018, 172, 138-154. [CrossRef]

13. Nord, L.; Bolland, O. Steam Bottoming Cycles Offshore-Challenges and Possibilities. J. Power Technol. 2013, 92, 201-207. Available online: https://www.researchgate.net/publication/259840669_Steam_bottoming_cycles_offshore_--_Challenges_and_ possibilities (accessed on 9 November 2021).

14. Nord, L.; Bolland, O. Design and Off-Design Simulations of Combined Cycles for Offshore Oil and Gas Installations. Appl. Therm. Eng. 2013, 54, 85-91. [CrossRef]

15. Kloster, P. Energy Optimization on Offshore Installations with Emphasis on Offshore and Combined Cycle Plants. In Proceedings of the Offshore Europe Conference 1999, Aberdeen, UK, 7-9 September 1999; Society of Petroleum Engineers Inc.: Richardson, TX, USA, 1999. [CrossRef]

16. Kloster, P. Reduction of Emissions to Air through Energy Optimisation on Offshore Installations. In Proceedings of the SPE International Conference on Health, Safety, and the Environment in Oil and Gas Exploration and Production 2000, Stavanger, Norway, 26-28 July 2000; Society of Petroleum Engineers Inc.: Richardson, TX, USA, 2000. [CrossRef]

17. Global Marine Fuel Trends 2030. Available online: http://discovery.ucl.ac.uk/1472843/1/Global_Marine_Fuel_Trends_2030.pdf (accessed on 25 June 2021).

18. Bianchi, M.; Branchini, L.; de Pascale, A.; Peretto, A. Application of Environmental Performance Assessment of CHP Systems with Local and Global Approaches. Appl. Energy 2014, 130, 774-782. [CrossRef]

19. Olympios, A.V.; Pantaleo, A.M.; Sapin, P.; Markides, C.N. On the Value of Combined Heat and Power (CHP) Systems and Heat Pumps in Centralized and Distributed Heating Systems: Lessons from Multi-Fidelity Modelling Approaches. Appl. Energy 2020, 274, 115261. [CrossRef]

20. Li, L.; Mu, H.; Gao, W.; Li, M. Optimization and Analysis of CCHP System Based on Energy Loads Coupling of Residential and Office Buildings. Appl. Energy 2014, 136, 206-216. [CrossRef]

21. Bonforte, G.; Buchgeister, J.; Manfrida, G.; Petela, K. Exergoeconomic and Exergoenvironmental Analysis of an Integrated Solar Gas Turbine/Combined Cycle Power Plant. Energy 2018, 156, 352-359. [CrossRef]

22. Liu, Z.; Karimi, I.A. New Operating Strategy for a Combined Cycle Gas Turbine Power Plant. Energy Convers. Manag. 2018, 171, 1675-1684. [CrossRef]

23. Van Erdeweghe, S.; Van Bael, J.; Laenen, B.; D’haeseleer, W. Design and Off-Design Optimization Procedure for Low-Temperature Geothermal Organic Rankine Cycles. Appl. Energy 2019, 242, 716-731. [CrossRef]

24. Hoang, A.T. Waste Heat Recovery from Diesel Engines Based on Organic Rankine Cycle. Appl. Energy 2018, 231, 138-166. [CrossRef]

25. Imran, M.; Haglind, F.; Asim, M.; Zeb Alvi, J. Recent Research Trends in Organic Rankine Cycle Technology: A Bibliometric Approach. Renew. Sustain. Energy Rev. 2018, 81, 552-562. [CrossRef]

26. Sanaye, S.; Amani, M.; Amani, P. 4E Modeling and Multi-Criteria Optimization of CCHPW Gas Turbine Plant with Inlet Air Cooling and Steam Injection. Sustain. Energy Technol. Assess. 2018, 29, 70-81. [CrossRef]

27. Guteša Božo, M. Fuel Rich Ammonia-Hydrogen Injection for Humidified Gas Turbines. Appl. Energy 2019, 251, 113334. [CrossRef] 
28. Han, W.; Jin, H.; Zhang, N.; Zhang, X. Cascade Utilization of Chemical Energy of Natural Gas in an Improved CRGT Cycle. Energy 2007, 32, 306-313. [CrossRef]

29. Jin, H.; Hong, H.; Cai, R. A Chemically Intercooled Gas Turbine Cycle for Recovery of Low-Temperature Thermal Energy. Energy 2006, 31, 1554-1566. [CrossRef]

30. Carapellucci, R.; Milazzo, A. Thermodynamic Optimization of a Reheat Chemically Recuperated Gas Turbine. Energy Convers. Manag. 2005, 46, 2936-2953. [CrossRef]

31. Zhang, N.; Lior, N. Use of Low/Mid-Temperature Solar Heat for Thermochemical Upgrading of Energy, Part I: Application to a Novel Chemically-Recuperated Gas-Turbine Power Generation (SOLRGT) System. J. Eng. Gas Turbines Power 2012, 134, 072301. [CrossRef]

32. Pashchenko, D. Energy Optimization Analysis of a Thermochemical Exhaust Gas Recuperation System of a Gas Turbine Unit. Energy Convers. Manag. 2018, 171, 917-924. [CrossRef]

33. Carapellucci, R.; Giordano, L. Upgrading Existing Gas-Steam Combined Cycle Power Plants Through Steam Injection and Methane Steam Reforming. Energy 2019, 173, 229-243. [CrossRef]

34. Cappelletti, A.; Martelli, F. Investigation of a Pure Hydrogen Fueled Gas Turbine Burner. Int. J. Hydrogen Energy 2017, 42, 10513-10523. [CrossRef]

35. Schönborn, A.; Sayad, P.; Konnov, A.A.; Klingmann, J. OH*-Chemiluminescence during Autoignition of Hydrogen with Air in a Pressurised Turbulent Flow Reactor. Int. J. Hydrogen Energy 2014, 39, 12166-12181. [CrossRef]

36. Valera-Medina, A.; Pugh, D.G.; Marsh, P.; Bulat, G.; Bowen, P. Preliminary Study on Lean Premixed Combustion of AmmoniaHydrogen for Swirling Gas Turbine Combustors. Int. J. Hydrogen Energy 2017, 42, 24495-24503. [CrossRef]

37. Pan, F.; Cheng, X.; Wu, X.; Wang, X.; Gong, J. Thermodynamic Design and Performance Calculation of the Thermochemical Reformers. Energies 2019, 12, 3693. [CrossRef]

38. Chen, J.; Liu, B.; Gao, X.; Xu, D. Production of Hydrogen by Methane Steam Reforming Coupled with Catalytic Combustion in Integrated Microchannel Reactors. Energies 2018, 11, 2045. [CrossRef]

39. Kyriakides, A.-S.; Voutetakis, S.; Papadopoulou, S.; Seferlis, P. Integrated Design and Control of Various Hydrogen Production Flowsheet Configurations via Membrane Based Methane Steam Reforming. Membranes 2019, 9, 14. [CrossRef] [PubMed]

40. Pashchenko, D.I. Thermochemical Recovery of Heat Contained in Flue Gases by Means of Bioethanol Conversion. Therm. Eng. 2013, 60, 438-443. [CrossRef]

41. Pashchenko, D. Thermodynamic Equilibrium Analysis of Combined Dry and Steam Reforming of Propane for Thermochemical Waste-Heat Recuperation. Int. J. Hydrogen Energy 2017, 42, 14926-14935. [CrossRef]

42. Pashchenko, D. First Law Energy Analysis of Thermochemical Waste-Heat Recuperation by Steam Methane Reforming. Energy 2018, 143, 478-487. [CrossRef]

43. Pan, F.; Zheng, H.; Liu, Q.; Yang, R. Design and Performance Calculations of Chemically Recuperated Gas Turbine on Ship. Proc. Inst. Mech. Eng. Part A J. Power Energy 2013, 227, 908-918. [CrossRef]

44. Newby, R.A.; Yang, W.-C.; Bannister, R.L. Use of Thermochemical Recuperation in Combustion Turbine Power Systems. In Turbo Expo: Power for Land, Sea, and Air, Proceedings of the ASME 1997 International Gas Turbine and Aeroengine Congress and Exhibition, Orlando, FL, USA, $2-5$ June 1997; American Society of Mechanical Engineers: New York, NY, USA, 1997. [CrossRef]

45. Sadeghi, M.; Chitsaz, A.; Marivani, P.; Mahmoudi, S.M.S. Effects of Thermophysical and Thermochemical Recuperation on the Performance of Combined Gas Turbine and Organic Rankine Cycle Power Generation System: Thermoeconomic Comparison and Multi-Objective Optimization. Energy 2020, 210, 118551. [CrossRef]

46. Nguyen, T.; Elmegaard, B.; Pierobon, L.; Haglind, F; Breuhaus, P. Modelling and Analysis of Offshore Energy Systems on North Sea Oil and Gas Platforms. In Proceedings of the 53rd SIMS conference on Simulation and Modelling, Reykjavik, Iceland, 4-6 October 2012; Available online: https:/ / backend.orbit.dtu.dk/ws/portalfiles/portal/38487211/content.pdf (accessed on 19 June 2021).

47. Foss, M.M. Interstate Natural Gas_Quality Specifications \& Interchangeability. Center for Energy Economics. 2004. Available online: https:/ / www.beg.utexas.edu/files / energyecon/global-gas-and-lng/CEE_Interstate_Natural_Gas_Quality_Specifications_ and_Interchangeability.pdf (accessed on 19 June 2021).

48. Oil \& Gas Industry Overview. Crude Oil and Natural Gas: From Source to Final Products. Available online: https://www.ihrdc. com/els/po-demo/module01/mod_001_02.htm (accessed on 19 June 2021).

49. WÄRTSILÄ. Wärtsilä Methane Number Calculator. Available online: https://www.wartsila.com/marine/build/gas-solutions / methane-number-calculator (accessed on 19 June 2021).

50. Cengel, Y.A.; Boles, A.M. Thermodynamics: An Engineering Approach, 8th ed.; McGraw-Hill: New York, NY, USA, 2015.

51. Farry, M. Ethane from Associated Gas Still the Most Economical. Oil Gas J. 1998, 96, 23.

52. Al-Saleh, M.A.; Duffuaa, S.O.; Al-Marhoun, M.A.; Al-Zayer, J.A. Impact of Crude Oil Production on the Petrochemical Industry in Saudi Arabia. Energy 1991, 16, 1089-1099. [CrossRef]

53. Antzara, A.; Heracleous, E.; Bukur, D.B.; Lemonidou, A.A. Thermodynamic Analysis of Hydrogen Production via Chemical Looping Steam Methane Reforming Coupled with in Situ $\mathrm{CO}_{2}$ Capture. Int. J. Greenh. Gas Control 2015, 32, 115-128. [CrossRef]

54. Dupont, V.; Twigg, M.V.; Rollinson, A.N.; Jones, J.M. Thermodynamics of Hydrogen Production from Urea by Steam Reforming with and without in Situ Carbon Dioxide Sorption. Int. J. Hydrogen Energy 2013, 38, 10260-10269. [CrossRef] 
55. Adiya, Z.I.S.G.; Dupont, V.; Mahmud, T. Chemical Equilibrium Analysis of Hydrogen Production from Shale Gas Using Sorption Enhanced Chemical Looping Steam Reforming. Fuel Process. Technol. 2017, 159, 128-144. [CrossRef]

56. Tartakovsky, L.; Baibikov, V.; Gutman, M.; Poran, A.; Veinblat, M. Thermo-Chemical Recuperation as an Efficient Way of Engine's Waste Heat Recovery. Appl. Mech. Mater. 2014, 659, 256-261. [CrossRef]

57. Özkara-Aydınoğlu, Ş. Thermodynamic Equilibrium Analysis of Combined Carbon Dioxide Reforming with Steam Reforming of Methane to Synthesis Gas. Int. J. Hydrogen Energy 2010, 35, 12821-12828. [CrossRef]

58. Lwin, Y.; Daud, W.R.W.; Mohamad, A.B.; Yaakob, Z. Hydrogen Production from Steam-Methanol Reforming: Thermodynamic Analysis. Int. J. Hydrogen Energy 2000, 25, 47-53. [CrossRef]

59. Nitsenko, V.; Mardani, A.; Streimikis, J.; Shkrabak, I.; Klopov, I.; Novomlynets, O.; Podolska, O. Criteria for Evaluation of Efficiency of Energy Transformation Based on Renewable Energy Sources. Montenegrin J. Econ. 2018, 14, 237-247. [CrossRef]

60. Zahid, U.; Al Rowaili, F.N.; Ayodeji, M.K.; Ahmed, U. Simulation and Parametric Analysis of $\mathrm{CO}_{2}$ Capture from Natural Gas Using Diglycolamine. Int. J. Greenh. Gas Control 2017, 57, 42-51. [CrossRef]

61. Imran, U.; Ahmad, A.; Othman, M. Kinetic Based Simulation of Methane Steam Reforming and Water Gas Shift for Hydrogen Production Using Aspen Plus. Chem. Eng. Trans. 2017, 56, 1681-1686. [CrossRef]

62. Bazaluk, O.; Havrysh, V.; Nitsenko, V.; Baležentis, T.; Streimikiene, D.; Tarkhanova, E.A. Assessment of Green Methanol Production Potential and Related Economic and Environmental Benefits: The Case of China. Energies 2020, 13, 3113. [CrossRef]

63. Bazaluk, O.; Havrysh, V.; Nitsenko, V. Energy and Environmental Assessment of Straw Production for Power Generation. E3S Web Conf. 2021, 228, 01010. [CrossRef]

64. Bazaluk, O.; Havrysh, V.; Nitsenko, V. Energy Efficiency of Inland Waterways Transport for Agriculture: The Ukraine Case Study. Appl. Sci. 2021, 11, 8937. [CrossRef]

65. Durán, F.J.; Dorado, F.; Sanchez-Silva, L. Exergetic and Economic Improvement for a Steam Methane-Reforming Industrial Plant: Simulation Tool. Energies 2020, 13, 3807. [CrossRef]

66. Chukurna, O.; Nitsenko, V.; Kralia, V.; Sahachko, Y.; Morkunas, M.; Volkov, A. Modelling and Managing the Effect of Transferring the Dynamics of Exchange Rates on Prices of Machine-Building Enterprises in Ukraine. Pol. J. Manag. Stud. 2019, 19, 117-129. [CrossRef]

67. Bazaluk, O.; Havrysh, V.; Fedorchuk, M.; Nitsenko, V. Energy Assessment of Sorghum Cultivation in Southern Ukraine. Agriculture 2021, 11, 695. [CrossRef]

68. Havrysh, V.; Nitsenko, V.; Bilan, Y.; Streimikiene, D. Assessment of optimal location for a centralized biogas upgrading facility. Energy Environ. 2019, 3, 462-480. [CrossRef]

69. Kurz, R.; Meher-Homji, C.; Brun, K.; Moore, J.; Gonzalez, F. Gas Turbine Performance and Maintenance. In Turbomachinery and Pump Symposia, Proceedings of the Forty-Second Turbomachinery Symposium, Houston, TX, USA, 1-3 October 2013; Texas A\&M University, Turbomachinery Laboratories: College Station, TX, USA, 2013; Available online: https://core.ac.uk/download/pdf/ 147258443.pdf (accessed on 25 July 2021).

70. Jin, H.; Hong, H.; Wang, B. A New Principle of Synthetic Cascade Utilization of Chemical Energy and Physical Energy. Sci. China Ser. E Eng. Mater. Sci. 2005, 4, 163-179. [CrossRef]

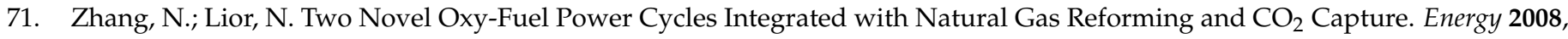
33, 340-351. [CrossRef]

72. Cherednichenko, O.; Havrysh, V.; Shebanin, V.; Kalinichenko, A.; Mentel, G.; Nakonieczny, J. Local Green Power Supply Plants Based on Alcohol Regenerative Gas Turbines: Economic and Environmental Aspects. Energies 2020, 13, 2156. [CrossRef]

73. Kalinichenko, A.; Havrysh, V.; Hruban, V. Heat Recovery Systems for Agricultural Vehicles: Utilization Ways and Their Efficiency. Agriculture 2018, 8, 199. [CrossRef]

74. Havrysh, V.; Kalinichenko, A.; Mentel, G.; Mentel, U.; Vasbieva, D.G. Husk Energy Supply Systems for Sunflower Oil Mills. Energies 2020, 13, 361. [CrossRef]

75. Briesch, M.S.; Bannister, R.L.; Diakunchak, I.S.; Huber, D.J. A Combined Cycle Designed to Achieve Greater Than 60 Percent Efficiency. J. Eng. Gas Turbines Power 1995, 117, 734-741. [CrossRef]

76. Franchi, G.; Capocelli, M.; De Falco, M.; Piemonte, V.; Barba, D. Hydrogen Production via Steam Reforming: A Critical Analysis of MR and RMM Technologies. Membranes 2020, 10, 10. [CrossRef] [PubMed]

77. Zhang, K.; Shen, Y.; Duwig, C. Finite Rate Simulations and Analyses of Wet/Distributed Flame Structure in Swirl-Stabilized Combustion. Fuel 2021, 289, 119922. [CrossRef]

78. Offshore Gas Turbines (and Major Driven Equipment) Integrity and Inspection Guidance Notes, RESEARCH REPORT 430. Published by the Health and Safety Executive 2006. Available online: https://www.hse.gov.uk/research/rrhtm/rr430.htm (accessed on 30 July 2021).

79. Mazzetti, M.; Neksã, P.; Walnum, H.; Hemmingsen, A. Energy-Efficient Technologies for Reduction of Offshore $\mathrm{CO}_{2}$ Emissions. Oil Gas Facil. 2014, 3, 89-96. [CrossRef]

80. Offshore Gas Turbines and Dry Low NOx Burners. An Analysis of the Performance Improvements (PI) Limited Database. THE UK OIL AND GAS INDUSTRY ASSOCIATION LIMITED (Trading as Oil \& Gas UK). 2015. Available online: https: / / silo.tips/download/offshore-gas-turbines-and-dry-low-nox-burners-an-analysis-of-the-performance-imp (accessed on 9 August 2021). 
81. Wärtsilä 50DF Product Guide. Vaasa. June 2018. Available online: https://cdn.wartsila.com/docs/default-source/product-files / engines / df-engine/product-guide-o-e-w50df.pdf?sfvrsn=9 (accessed on 31 July 2021).

82. Wärtsilä 46DF Product Guide. Vaasa. November 2019. Available online: https://www.wartsila.com/docs/default-source/ product-files/engines /df-engine/product-guide-o-e-w46df.pdf?utm_source=engines\&utm_medium=dfengines\&utm_term= w46df\&utm_content=productguide\&utm_campaign=msleadscoring (accessed on 31 July 2021).

83. Rostrup-Nielsen, J.; Christiansen, L.J. Concepts in Syngas Manufacture; Imperial College Press: London, UK, 2011; p. 392. ISBN 978-1-84816-567-0.

84. Power Generation Product Selection Guide. Solar Turbines. A Caterpillar Company. Available online: https:/ / pdf.directindustry. com/pdf/solar-turbines/power-generation-product-selection-guide/22650-1684.html (accessed on 9 August 2021).

85. Haglind, F. Variable Geometry Gas Turbines for Improving the Part-Load Performance of Marine Combined Cycles - Gas Turbine Performance. Energy 2010, 35, 562-570. [CrossRef]

86. SGT-600 Industrial Gas Turbine. Available online: http://www.heinkel-systeme.de/data/simple/0056/Heinkel_Gas_Turbine_ SGT-600_GT_PowerGen_EN.pdf (accessed on 9 August 2021).

87. Powering the World 2016. Available online: https://pdf.directindustry.com/pdf/ge-gas-turbines/powering-world-2016/34155 -648066.html (accessed on 23 August 2021).

88. Larfeldt, J. Applying Simulation and Additive Manufacturing to the Development of Next Generation of Hydrogen Combustion. 2017. Available online: https://www.international-bc-online.org/wp-content/uploads/2018/04/2_-Hydrogen_cofiring_ Larfeldt_13april2018.pdf (accessed on 15 August 2021).

89. 6B.03 Gas Turbine. Available online: https://www.ge.com/gas-power/products/gas-turbines/6b (accessed on 15 August 2021).

90. Is IGCC a Viable Option for Biomass? Workshop IEA Bioenergy Task 33. Lucerne. 26 October 2016. Available online: http:/ / www.ieatask33.org/app/webroot/files/file/2016/IGCC.pdf (accessed on 15 August 2021).

91. Igoe, B.M.; Stocker, A. Extended Fuels Capability of Siemens' SGT-400 DLE Combustion System. Available online: https: //nanopdf.com/download/extended-fuels-capability-of-siemens-sgt-400-dle-combustion-system-andy-stocker_pdf (accessed on 15 August 2021).

92. Koval, V.; Sribna, Y.; Mykolenko, O.; Vdovenko, V. Environmental Concept of Energy Security Solutions of Local Communities Based on Energy Logistics. Int. Multidiscip. Sci. GeoConf. SGEM 2019, 19, 283-290. [CrossRef]

93. Kalinichenko, A.; Havrysh, V.; Atamanyuk, I. The Acceptable Alternative Vehicle Fuel Price. Energies 2019, 12, 3889. [CrossRef]

94. Mikhno, I.; Koval, V.; Shvets, G.; Garmatiuk, O.; Tamošiūnienė, R. Discussion: Green Economy in Sustainable Development and Improvement of Resource Efficiency. Cent. Eur. Bus. Rev. 2021, 10, 1-15. [CrossRef] 